\title{
Türk ve Dünya Mitolojilerinde Sirius Kültü
}

\section{Sirius Cult in Turkish and World Mythologies}

\section{Yaprak Pelin ULUIŞIK*}

Öz: Yaratılışından itibaren insanoğlu, varoluşunu ve evreni anlayabilmek adına sürekli gözlemde bulunmuştur. Gökyüzü, onun gözlem yapabilmesi ve bir şeyleri anlamlandırabilmesi için sonsuz bir kaynak oluşturmuştur. Birtakım benzetmeler ile başarılı tespitler, önemli hesaplamalar yapan insan toplulukları, var oldukları dönemin en büyük medeniyetlerini kurmaya da vâkıf olmuştur. Sirius Takımyıldızı, medeniyetlerin gökyüzü ile ilgili benzetmelerine, anlatmalarına ve hesaplamalarına en çok konu olan yıldızlardandır. Bu çift yıldıza medeniyetler gizemli bir şekilde önem vermiştir. Bu makale, bu gizemin ortaya konulması ve Türklerin de bu gizeme sahip anlatmalarının tespit edilip değerlendirilmesi ile ilgilidir. Siriusyen kültür için önemli semboller olan gök tanrı, 1şık, yıldız, ok ve yay ile kurt ve köpek unsurları, dünya mitolojilerinde ve Türk mitolojisinde paralellik gösteren örnekleri ile bu makalede ele alınmıştır. Dünya mitolojisi kapsamında Sirius'u işaret eden Eski Mısır, Hellen, Mezopotamya, Çin ve Hint mitlerine; Türk mitolojisi kapsamında ise Sirius ile ilgili olabileceği düşünülen Türk destan, efsane, masal vb. halk anlatılarına yer verilmiştir.

Anahtar sözcükler: Sirius, Gök Tanrı, Işık, Yıldız, Ok-Yay, Kurt-Köpek

Abstract: Since creation, mankind has been constantly observing in order to understand its own existence and that of the universe. The sky has provided an endless source for them to be able to observe and understand their surroundings. Human societies made successful discoveries and made crucial calculations employing metaphors and, in consequence, they managed to establish the greatest civilizations of the time. The constellation of Sirius is one of the constellations that has always been a primary subject of metaphors, narratives and calculations for different civilizations. Almost all civilizations have mysteriously attached ultimate importance to this pair of stars. This article aims to present this mystery through identifying and evaluating Turkish narratives that contain it. The crucial symbols of a Sirius culture such as: sky god, light, star, arrow, bow, wolf and dog and which are similar in Turkish and world mythologies have been studied in this article. Within the context of world mythology the ancient Egyptian, ancient Greek, Mesopotamian, Chinese and Indian myths and within the scope of Turkish mythology, Turkish epics, legends and tales concerning the cult of Sirius are all mentioned in this article.

Keywords: Sirius, Sky God, Light, Star, Arrow-Bow, Wolf-Dog

\section{Giriş}

İnsanoğlu gökyüzünü, ondaki göksel unsurları ve yıldızları anlamlandırılmaya çalıştıkça yıldızlardan gelen kozmik etkileri fark etmiş, yıldızların sahip olduğuna inandığı güce sayg1 duymaya başlamıştır. Öyle ki, dünya üzerinde bazı coğrafyalarda, çeşitli dönemlerde yıldızlara

\footnotetext{
*Dr., Gazi Üniversitesi, Edebiyat Fakültesi, Türk Dili ve Edebiyatı Bölümü, Ankara. ypeline@hotmail.com Bu makale “Sirius Kültürü ve Türk Mitolojisi Illişkisi” tezimden özetlenerek hazırlanmıştır.
} 
tapıldığı dahi görülmektedir. Eskiler, değişik doğumlar ve büyük değişimler sırasında her şeyin, o anda ortaya çıkan ve tüm canlıları etkilediği düşünülen bir ya da birkaç takımyıldızı tarafından belirlendiğine inanmıştır (Hope 1994, 305). Bu takımyıldızlardan biri de Sirius'tur. Sirius Takımyıldızı, Büyük Köpek Takımyıldızı'na bağlı birer yıldız olan "Sirius A" ve "Sirius B"nin oluşturduğu bir yıldız çiftidir. Sirius A, gökyüzünde Güneş’ten sonraki en parlak yıldızdır. Sirius B ise bir akcücedir; giderek sönmüş, dış kabuğunu atmıştır. Sirius B yıldızı, çevresindeki nesnelere müthiş bir çekim kuvveti uygulamaktadır; bu nedenle kendisinden 160.000 kez büyük olan Sirius A'yı çekim kuvveti ile etkilemektedir. Bunun sonucunda Sirius A ve Sirius B birbirleri etrafında, yaklaşık elli yılda (49.9 yılda) tamamlanan bir yörünge çizerek sürekli olarak dönmektedir.

Latince kullanımı yaygın olan "Sirius", köken itibarıla Latince değildir. Latince'ye Hellence'den geçen bu yıldızın adı Hellas'ta "Seirios" şeklinde kullanılmıştır ve anlamı "parlaklık, ateş; aşırı sıcak gün"dür. Eski Mısır'da "Sopdet" adı verilen yıldızın Eski Mısır dilinden Hellence'ye uyarlanmış hali "Sothis"tir. Mezopotamya sahasında Sirius adının "Kak-sisa”, "Kak-si-di", "Kak-si-si” şeklinde kullanıldığı görülmektedir. Sanskritçe'de "Mrgavyadha" veya "Lubdhaka" olarak bilinen Sirius Yıldızı, "avcı" manasına gelmektedir. İskandinavya'da Sirius Yıldızı için "Lokabrenna” denir ve "Loki’nin meşalesi, Loki tarafindan yakılmış" anlamındadır. Çinliler bu yıldız takımına "Hu-Şi" adını verir ve bu kelime, "yay ve ok" manasındadır. Japonlar bu yıldıza "Aoboshi" demektedir ve anlamı "mavi yıldız"dır. Dogonların "Sigi", Bambaraların "Sigo", Bozoların "Sima Kayne" dedikleri bu yıldıza Araplar "Şi 'ra" demiştir ve bu kelime Arapça' da "işaret, rehber, kılavuz" manasına gelmektedir (Salt \& Çobanlı 2001, 392).

Birçok kutsal kitapta sözü edilen Sirius Takımyıldızı, yeryüzündeki bazı uygarlıklar için de en kutsal yıldız olmuştur. Eskilerin "cennetlerin en görkemli yıldızı" dediği bu çift yıldız ile ilgili Mu, Atlantis, Eski Mısır, Hellen, Roma, Mezopotamya, Anadolu, Çin, Hint; Afrika yerlileri, Hopi Kızılderilileri, İskandinav halkı ve Şamanist Türkler gibi pek çok medeniyetin ve topluluğun kendi içinde çeşitli inanmalara, anlatmalara ve pratiklere sahip olduğu görülmüştür. Sümer'de “Evrenin Yargıcı”, Eski Mısır'da "Yüce Rızık Verici”, Dogonlarda "Rahmet Yıldızı", Bozolarda "Göz Yıldızı", Bambaralarda "Bilginin İki Yıldızı", Zend Avesta'da "Muhteşem Yıldız", Markiz Adaları'nda "Yüce Yıldız”; Hellas, Roma ve Perslerde "Köpek Yıldızı"; Çinlilerde "Yay ve Ok Yıldızı" gibi manalar ile bilinen bu çift yıldız hakkında araştırmalar derinleştirildikçe "Siriusyen kültür" adı altında yepyeni bir kültür dairesi ile karşılaşılmıştır. En gelişmiş medeniyetlerin yer aldığ 1 coğrafyalarda Sirius'un aynı şeklide tasvir edilmesi, benzer anlatmalara sahip olması ve etrafında oluşturulan pratiklerin birbirini andırması dikkat çekicidir.

Siriusyen kültürün temelinde, Sirius'ta (Sirius A'dan ziyade Sirius B'de) ikamet eden Tanrı ve onun elçileri olan Sirius varlıkları mevcuttur. Bu varlıklar, Siriusyen kültürü çeşitli zamanlarda çeşitli topluluklara yaymak ile görevlendirilmiştir. Tanrının yardım etmek istediği milletlerin, ilerlemesini istediği medeniyetlerin doğuşlarında veya yükselişlerinde ortaya çıkan bu Tanrı elçileri, Tanrının yardımlarını yeryüzüne bizzat getirmiştir. Bu kültürün temeli $\mathrm{Mu}$ ve Atlantis'e dayandırılmaktadır. Bu iki kıta yok olmadan önce Sirius elçileri veya Atlantis rahipleri tarafından Eski Mısır'a Sirius sırlarının getirildiği ve Eski Mısırlı din adamlarının bu konuda eğitildiği düşünülmektedir. Bir sır şeklinde getirildiği ve bilgisinin herkese verilmemesi gerektiği için de Mısır mabetlerinin derinliklerinde saklı tutulduğu ve kimseye açıklanmadığı tahmin edilmektedir. Eski Mısır dışında önemli uygarlıklara da bu tip elçilerin veya Sirius'a işaret eden müdahalelerin geldiği, fakat bunların da birer sır olarak kaldığı inanmalardan, anlatmalardan ve pratiklerden anlaşılmaktadır. 


\section{Dünya Mitolojilerinde Sirius}

Eski Mısır'da Sirius Takımyıldızı "Yeni Gün”, “Yeni Ay”, “Yay Yıldızı” ve “Büyük Rızık Verici” gibi isimler almıştır ve Mısır'ın en ünlü yarı tanrıları İsis, Osiris, Set, Neftis ve Horus, bu takımyıldız ile ilişkilendirilmiştir (Mısırlılar Güneş, Ay ve Sothis/Sirius takvimlerini kullanmıştır. Sirius takviminde 360 güne ek beş gün vardır ki bunlar bu beş yarı tanrı şeklinde düşünülmüştür) Dünyadaki düzeni sağlamak ve insanlığı eğitmek için Sirius A ve B'den geldikleri düşünülen, tanrı vasıflarına sahip bu yöneticilerden İsis, Sirius A'nın; Osiris ise Sirius B'nin temsilcisi olarak kabul edilmiştir. İsis dişidir, aydınlığın sembolüdür, beş köşeli yıldız onun yıldızıdır ve o, gök mavisi renk ile tasvir edilir ki bu özelikler, Mısır inanışlarına göre aynı zamanda Sirius A'nın da özellikleridir. Osiris ise erildir, İsis'in eşi ve refakatçisidir, Set tarafindan öldürüldügünde bir süre ortadan kaybolmuştur ve teni yeşil, elbisesi ise beyaz renkte tasvir edilir ki bunlar da inanışa göre Sirius B’nin özellikleridir (Hope 1998, 231-232). Sirius ile ilişkilendirilebilecek bir de çakal başlı Anubis vardır. Anubis, tanrıların bir yıldız metalinden yapıldığına inanılan, ağır asasını taşır; bu dünya ile diğer dünya arasındaki elçidir ve ruhların yöneticisidir. $\mathrm{Bu}$ nedenle onun, Sirius $\mathrm{A}$ ve $\mathrm{B}$ arasındaki yörüngeyi temsil ettiğine inanılır (Temple 1999, 133-134). Sirius'un gökyüzünden yetmiş gün süren kayboluşu, Eski Mısır'da ölüm ile bir düşünülmüştür; bu nedenle cesetlerin mumyalanma süresi yetmiş gündür. Yetmiş gün sonra mumyalanan cesedin (Sirius'un tekrar gökyüzünde parlaması -helyak doğuş- gibi) yeniden canlanacağına inanılır (Temple 1999, 172). Mısırlıların yaşam kaynağı olan Nil, Sirius'un yeniden ortaya çıkması ile aynı zamanda taşar ve doğa yeniden hayat bulur. $\mathrm{Bu}$ nedenle insanlar, Sirius A'yı takip ederek Nil'in ne zaman taşacağını hesaplamışlardır; bu, onların su ve toprak ile olan bağlarını güçlendirmiştir. Mısır piramitlerinin ve diğer tapınakların en önemli odalarının Sirius'un ışığını alabilecek şekilde inşa edilmiş olması ve bu tapınakların bazılarında Sirius A ve B'nin yay ve ok ile tasvir edilmesi (Salt \& Çobanlı 2001, 394) ile Sirius'un bir adının da "Yay Yıldızı" olması dikkate değerdir.

Hellas’ta Sirius Takımyıldızı için “Köpek Yıldızı” veya "Orion’un Köpeği” isimleri kullanılmıştır ve Sirius'un yeniden gökyüzünde belirdiği dönem sıcak ve kurak bir yazı haber verdiği için bu yıldızın olumsuz etkileri olduğuna inanılmıştır. Bu nedenle Hellenler arasında en sıcak günler, "köpek günleri” olarak ifade edilir (Holberg 2007, 16-17). Homeros'un İlyada Destanı'nın 22. bölümünde Sirius için “yıldızların en parlağı” denilir ve onun gökyüzünde belirmesinin birçok insana sıtma hastalığını getirdiği söylenir (Hom. Il. XXII.). Ege Denizi'ndeki Keos (Kea) Adası'nda, soğukların azalması için Sirius ve Zeus'a kurban sunulduğu bilinir. Ayrıca bu adada, MÖ III. yüzyılda kullanılan paralarda köpek ve yıldız tasvirleri ile Sirius'a işaret edilmiştir (Holberg 2007, 16-17). Hellas'ta Sirius Takımyıldızı sadece köpek ile değil kurt ile de ilişkilendirilmiştir. MÖ VIII. yüzyılda, Mora Yarımadası'ndaki Arkadia Bölgesi'nde kurda dönüşen insanların anısına "Zeus Lykaios"a tapılmıştır (Estin \& Laporte 2007, 102). Zeus'un adına eklenen "lykaios” kelimesindeki "lyk", Helence "kurt" demektir. Hellen mitolojisindeki Apollon ve Artemis kardeşlerin, Sirius Takımyıldızı ile ilgili olarak verilebilecek iyi örneklerden oldukları söylenebilir. Apollon'un da Zeus'un lakabı gibi "lyk" kökünden türetilmiş bir lakabı (Likyalı) vardır ve onun için kurt kurban edildiği bilinmektedir (Bonnefoy 2000, 48). Onun kız kardeşi Artemis de gümüş yayı ve attığ1 isabetli okları ile tanınır. Artemis aynı zamanda, Mısır mitolojisindeki İsis'in Hellen mitolojisindeki karşılığıdır. Bir anlatmada Aktaion adlı Hellen kahramanı, Artemis’i çıplak görür ve bu duruma çok sinirlenen Artemis, cehennem bekçisi 50 av köpeğini de alarak Aktaion'un peşine düşer ve oku ile onu öldürür (Temple 1999, 202). Köpeklerin "av köpeği”" olması Sirius'a, avcı Orion'un köpeği olmasından dolayı "Köpek Yıldızl” denilmesini hatırlatmaktadır. Apollon ve Artemis dışında Odysseia'nın baş kahramanı Odysseus'un köpeği 
Argos (“Arq", Mısır dilinde "bir devrin tamamlanması, döngünün bitmesi” manasındadır ve "Argos”, bu kökten türemiş bir isme sahiptir. Odysseus'un seferi bitince o, İthake’ye geri döner ve onu bir tek köpeği Argos tanır; bu sahnenin hemen ardından Argos ölür. Bu, bir dönemin bitip yeni bir dönemin başladığına ilişkin bir betimleme olarak kabul edilebilir. Ayrıca Hellence'de "argos”; “ı̧̧ı saçıcı”, "beyaz” ve "hızlı" manasındadır (Temple 1999, 309-310); Hades'in 3 / 50 / 100 başlı köpeği Kerberos ve onun "urt” yani "bir yıldızın batması" manasına gelen bir kökten türeyen ismi ile kardeşi Orthrus (Temple 1999, 304); ismi "ok gibi hedefi vuran" manasındaki "hekatos - hekatoboles"ten gelen ve başlarından birinin köpek başı olduğu bilinen Hekate ile onun kız kardeşi olan, elli kız çocuğuna sahip, çoban köpeği gibi ses çıkartan ve kurt bilekli olduğu söylenen Ay tanrıçası Selene (Bonnefoy 2000, 388); Kerberos ile Hekate'den olma, belinden köpek kafaları çıkan Skylla (Temple 1999, 356-357) da Sirius Takımyıldızı ile ilişkilendirilebilir. Hellas'ta son olarak Argos kralı Danaos ile Sirius bağlantısını ele almak gerekir. Elli kız çocuk babası olan Danaos, Mısır'dan Anubis elçiliğinde gelir ve geldiği topraklarda krallık mücadelesine girişir. Bu mücadele döneminde bir gün ormandan bir kurt çıkar ve o sırada şehrin önünden geçmekte olan sürüye saldırır; bir boğanın üzerine atlar ve onu öldürür. İnsanlar bu olayı, tanrısal iradenin bir tecellisi olarak görür ve Danaos ile ilişkilendirir. Bunun üzerine Danaos kral seçilir. Mısır'ın "Egypt" adını ondan aldığı Aigyptos, Danaos'un ikizidir ve onun da elli erkek çocuğu vardır (Grimal 1997, 137-139). Bu işaretlere bakıldığında Danaos ve Aigyptos'u, Sirius A ve Sirius B ile; onların ellişer çocuklarının olmasını ise Sirius A ve B'nin kendi yörüngelerindeki ellişer yıllık dönüşleri ile ilişkilendirmek mümkündür.

Hellen mitolojisinin bir devamı olarak görülen Roma mitolojisinde Romus ve Romulus kardeşlerin bir kurt tarafından kurtarılması, Sirius anlatmaları ile alakalı sayılabilecek bir örnektir. İlgili mitte Romus ve Romulus'un, düşmanları Amulis'in onları bıraktığı nehirden bir kurt tarafindan kurtarılıp emzirilmeleri ve büyüyen ikizlerin tekrar iktidarı ele geçirip Roma Krallı̆̆g'nı kurmaları anlatılır. Bu örneğe ek olarak, Romalılarda Sirius ve kurt/köpek bağlantıs1 hakkında, her yıl 25 Nisan civarı Sirius için, gökyüzünde yeniden belirmesi şerefine köpek kurban edilen bir törenden de bahsetmek mümkündür (Holberg 2007, 32).

Sümer temelli olmakla birlikte Akad, Asur, Babil ve Pers medeniyetlerinin izlerini de taşıyan ve bölgenin aldığı sürekli göçlerle, yaşadığı akınlarla beslenen, çok kültürlü Mezopotamya mitolojisinde, Sümerlerin göçebelik dönemleri sırasında, göçleri için yön saptamada yaşamsal önem taşıyan sağlam bir yıldız bilgisi edinmiş olmaları ve yerleşik düzene geçince de bu bilgileri ile ekim, biçim ve taşkın zamanlarını gökyüzündeki yıldızların değişen dizilimlerine göre saptayabilmek konusundaki başarıları önemli rol oynamaktadır. Sümer çiviyazısı öncesi resimyazısında tanrıların tanrı oldukları, bir yıldız simgesi ile resmedilmektedir. Yıldızlar ile ilgili bilgileri veren "astronom rahipler”, gökteki yıldızların uzaktan göründükleri gibi birer kor olmadıklarını; aslında çok büyük, güçlü ve bilgili canlı varlıklar olduklarını; kendilerinin de onlarla iletişim kurduklarını söylemiştir (Şenel 2009, 408-409).

Sümer-Akad kültürü aşağı yukarı Mısır çağdaşıdır. Sümer metinlerinde "Magan" şeklinde geçen ülkenin Mısır olduğu bilinmektedir (Temple 1999, 131). Mısır ile Sümer arasında pek çok ortak tanrı isminin ve ortak noktanın olması bu iki medeniyetin birbirleri ile temas halinde olduklarını göstermektedir. Örneğin Sümer'in baş tanrısı olan gök tanrısı Anu, çakal ile simgelenmektedir ve Mısır'da da köpek başlı Anubis bulunmaktadır. İsimlerinin benzerliği gözden kaçmayan bu iki tanrı dışında Sümer'de Anu'ya "An" da denilmektedir ki Mısır'daki Osiris'e de "An" denilir (Temple 1999, 151). Hem Anubis hem de Osiris, Misır' in Sirius ile ilişkilendirdiği tanrılar iken başta Sümer olmak üzere bütün Mezopotamya'nın gök tanrısı An da 
Mezopotamya bünyesinde Sirius ile ilişki kurulabilecek ilk ipucudur. An'ın kızı Bau, köpek başlı bir Sümer tanrıçasıdır ve onun Enlil'in oğlu olan eşi Ninurta, yay çekmedeki ustalığ ile tanınır (Bonnefoy 2000, 1059). Temple Bau'nun, İsis'in Sothis (Sirius) kimliğine denk bir köpek yıldız kavramının Mezopotamya'daki devamı olduğunu düşünmektedir (Temple 1999, 183). An, "kraliyet kanından olanlar" manasına gelen Anunnakiler'in de babasıdır. "Anuna / Anunnaki” sözcüğü erken dönem metinlerinde, özellikle Sümer'e ait metinlerde, ilk doğan ve özel adlarla farklılaştırılmayan eski tanrıları adlandırmak için kullanılmıştır (Black \& Green 2003, 31). Anunnaki, Akadçada "gökten yere inen elli" demektir (Salt 2010, 114). Anunnakiler kadere hakim oldukları söylenen elli refakatçi ilahtır. Onların sayısının elli olması, "elli" sayısı ve Sirius ilişkisi açısından önemlidir. Ayrıca onlara "refakatçi ilahlar" denilmesi de Sirius B'nin Sirius A'ya refakat ettiği şeklindeki tanımlamaları hatırlatmaktadır. Anunnakiler, Sümer'de bir "yay yıldızı" ile ilişkilendirilir ve bu ilahlar, "Tanrılar Meclisi" denilen bir mecliste oturmaktadır. Sümer yaratılış mitosunun temelini teşkil ettiği Enuma Eliş Babil Yaratılış Destanı'nda Anunnakilerin, Yay Yıldızı denilen bir kardeşlerinin olduğu ve Tanrılar Meclisi'nde Anunnakilerin tam ortasında oturduğu bilgisi yer almaktadır.

Hava tanrısı Enlil, Mezopotamya'nın en önemli tanrısıdır. Tanrıların babası ve evrenin kralı olduğu kabul edilen Enlil'in yerden göğü ayırdıktan sonra, tavanını ve duvarlarını 1şıksız göğün, yerini kara toprağın oluşturduğu evinde kendini zifiri karanlıkta yaşar bulduğu söylenir (Kramer 2001, 13). Bu durum, Sirius B'nin bir ak cüce olduğu ve artık sönerek Sirius A'nın yörüngesine çekilip karanlığa gömüldüğü gerçeği ile alakalı görünmektedir.

Tarihteki ilk yazılı destan olma özelliğini taşıyan ve Mezopotamya kültürünün anlatıldığı en önemli eserlerden olan Gılgamış Destanı'nda da Sirius'un izlerine rastlanmaktadır. Gılgamış da rüyasında ağır bir yıldız ile karşılaşır ve tüm çabasına rağmen onu kaldıramaz. Bu rüyayı her konuda ilim sahibi olan annesi Ninsun'a anlatırken yıldızın ona gökten indiğini söyler. Destanın bu bölümü eski bir Sümer tabletinde şu şekilde verilmiştir: “... / Gllgamış yatağından kalkar ve / Düşlerini anlatmaya başlar, annesine şöyle der: / 'Anam, dün gece bir düş düşledim. / Gökte yıldızlar vardl; / Yıldızlardan biri üstüme indi, sanki / Göklerin ev sahibinin özü / Ittelemeye çalıştım fakat olmadı' / ..." (Ramazanoğlu 1998, 53). Bu bölümün, yukarıdaki Sümer-Asur versiyonundan çok daha eski bir Babil versiyonu vardır ve bu versiyonda Gılgamış, yıldızın gök tanrısı Anu ile ilişkili olduğunu belirtir: “... / Gılgamış rüyasını anlatmaya yeltenip annesine şöyle dedi: / 'Anam, dün gece pek mutluydum / Asillerin arasında yürüdüm, / Gökte yıldızlar belirdi / Anu'nun yıldız özü bana doğru alçaldı / Kaldıracak olduysam da çok ă̆ırdı; kımıldatmak istediysem de olmadı' / ...” (Ramazanoğlu 1998, 54). Bu iki farklı versiyona ait Sirius ile ilgili olarak alınabilecek destan bölümlerinde Gılgamış, yıldızın "kudretli öz"ünden bahseder ve çok ağır olduğunu belirtir. "Anu'nun yıldız özü”, “ev sahibinin özü” şeklinde tasvir edilen yıldızda özellikle "öz" kelimesinin kullanması, "yoğunlaşma, cevher" manasını da hatırlatır (Temple 1999, 181). Sirius B'nin küçük olmasına karşın çok ağır bir yıldız olması ve astronomların bu yıldız için "evrim geçirmiş bir element" ya da "yoğun demir" ifadelerini kullanmaları bu kudretli, yoğun özden kastın Sirius B olması ihtimalini kuvvetlendirir. Gılgamış Destanı'nda ayrıca Gılgamış'ın elli isimsiz yoldaşından bahsedilmektedir (Bu elli yoldaş, Babil versiyonlarında çıkartılmıştır.). Elli mina (yirmi beş kilogram) ağırlığında zırhı olan Gılgamış, Magan gemisinde "rahimden çıkanlar" olarak ifade edilen elli kürekçi yoldaş ile birlikte anlatılmaktadır (Salt 2010, 114). Bu elli kürekçi de muhtemelen Sirius A ile Sirius B'nin yörünge sürelerine ait ve Mezopotamya mitolojisi ile ilişkili yeni bir ipucudur.

Mezopotamya'ya gelerek o bölgenin kültürünü kendi kültürleri ile birleştiren Perslerin geleneklerinde de Sirius’tan, “Ok Yıldızl” ve "Yay Yıldızı" dışında bir de "Köpek Yıldızı" olarak 
söz edilmektedir (Temple 1999, 522). Plutarkhos, Köpek Yıldız Sirius'un bir Pers tasvirinden bahsetmiştir. Bu tasvirde bir yumurtayı oluşturan dizili elli tanriyla çevrili olan "ışık tanrısı", "karanlık tanrı" ile yumurtada buluşur. Işık tanrısı Oromazes, saf 1şıktan doğar. Karanlık tanrısı Areimanius ise karanlıktan doğar. Bu iki tanrı sürekli olarak münakaşa içerisindedir. İkisi de yirmi beşer tane tanrı yaratır ve bu tanrılar bir yumurtaya konur. Sonra Oromazes kendini üç kat büyütür ve Güneş’ten, yeryüzü kadar uzak bir mesafeye giderek gökleri yıldızlarla donatır. Her şeyden önce yumurtaya bir yıldızı bekçi ve muhafız olarak yerleştirir ki bu yıldız, Köpek Yıldızı'dır (Salt \& Çobanlı 2001, 391). Yani elli tanrılı yumurta, Sirius A ve Sirius B'nin elli yıllık yörüngesidir ve Köpek Yıldızı da Sirius'tur.

Astrolojiye önem veren Çin'in geleneklerinde Sirius yıldızı, "göksel saray"ın bekçisi "göksel kurt”tur (Salt \& Çobanlı 2001, 208). Ayrıca bu yıldız, yay ile ifade edilmiştir ve Sirius'un Çince adı olan "Hu-Şi”, "yay ve ok" anlamında gelmektedir (Salt \& Çobanlı 2001, 394). Çin mitolojisi anlatmalarına bakıldığında en çok kullanılan motiflerin "yıldız tanrı", "kurt - köpek" ve "ok - yay" olduğu açıktır. Bu mitolojide beyazlıkları, parlaklıkları ve bilgilerinin güzelliği ile ünlü yıldız tanrılardan biri olan Tou Mu ile kuzeyde yaşayan Chou Yü kralının evliliklerinden dokuz tane erkek çocukları olur. Hep beraber Tou Mu'nun sarayına yerleşirler. Tüm yıldızlar bu sarayın etrafında dönmektedir. Dokuz oğlu da yakın yıldızlara yerleşir. Etrafına kutsal bir "lşıl" yayan Tou Mu'nun üç gözü olduğu ve elinde bir "yay" tuttuğu bilinmektedir (Werner 2008, 120-121). Çin mitolojisinde yıldız tanrıların oğulları, "imparatorluk" unvanının sahipleridir. İmparator Che, bir yıldız tanrısının oğludur. Bir gece annesi, küçük bir adaya doğru nehirde sürüklenen ve gökkuşağına benzeyen bir yıldız görür. Gece rüyasına giren bu yıldıza sahip olduğunu gören kadın, hamile kalır ve Che'yi doğurur. Che’den sonra gelen Chuen-Heugh da bir yıldız tanrının oğludur. Annesi bir yıldızın gökkuşağı gibi ayın içerisinden geçtiğini tesadüfen görür; hamile kalır ve oğlunu doğurur. Chuen-Heugh büyük bir bilgedir. İlk kez takvim hesaplarını o yapmıştır ve gök cisimlerinin yerlerini o kaydetmiştir (Werner 2008, 233).

MÖ 119'da Hunlar tarafından büyük bir yenilgiye uğratılan Tanrı Dağları'nın sakinleri WuSunlar, Sirius ile ilişkilendirilebilecek motiflerden biri olan "kurt" motifinin en önemli örneğine sahiptir. Hunlar, bir taarruz neticesinde Wu-Sun kralını öldürmüştür. Onun oğlu Kun-mo küçük olduğu için Hun hükümdarı ona kıyamamış ve onun çöle atılmasını, ölümü ile yaşamının kendi kaderine bırakılmasını emretmiştir. Küçük Kun-mo, çölde dişi bir kurt tarafından bulunup emzirilmiştir. Bu olayı uzaktan seyreden Hun hükümdarı, çocuğun kutsal bir çocuk olduğuna inanarak onu çölden aldırmış ve ona en iyi şekilde bakılmasını emretmiştir. Çocuk büyüyüp de bir yiğit olunca Hun hükümdarı onu ordularından birine komutan yapmıştır. Gittikçe gelişen ve başarılı olan bu çocuğa gönül bağlayan Hun hükümdarı, babasının eski devletini ona vererek Kun-mo’yu Wu-Sunların kralı yapmıştır (Ögel 2003, 14). Kurdun emzirmesi ile ilahi genlere sahip olma durumu, Sirius ile ilgili olarak incelenen mitolojilerin çoğunda mevcuttur. Bu durumda Kun-mo, Çin mitolojisinde Sirius tanrılarının veya Sirius'tan gelen elçilerin soyundan gelmektedir, denilebilir. Bu efsane, Romus ve Romulus hakkındaki anlatma ile benzerdir. Onları da bir su kenarında dişi bir kurt bulup emzirmiştir. Dişi kurt tarafindan emzirilmiş olma durumu, Gök Tanrının gönderdiği ilahi elçilerin, kahramanların yaşamasını sağlamasının bir göstergesidir. Bu sayede hayatta kalan çocuklar, ileride kendi devletlerinin başına geçecektir. $\mathrm{Bu}$ bir çeşit Gök Tanrıdan kut alma şeklidir. Bu benzer anlatmalardaki dişi kurt motifinin doğudan batıya $\mathrm{m} 1$ yoksa batıdan doğuya $\mathrm{m} 1$ geçtiği bilinmemektedir; eğer Siriusyen kültür açısından değerlendirilirse aslında böyle bir geçiş sürecinin olmamış olması gerekmektedir. Tanrının elçileri olan Sirius varlıkları, Gök Tanrının yardım etmek istediği milletlerin, ilerlemesini istediği medeniyetlerin doğuşlarında veya yükselişlerinde ortaya çıkmış ve tanrı 
yardımlarını kahramanlara bizzat getirmiş olmalıdır. Siriusyen kültür açısından Orta Asya'da ve Roma'da görülen kurtların bir anlatıdan doğan motifler olduğu düşünülmemelidir.

Eski Çin takviminin yeni yılında (şubat ayının ortalarında) Çinliler tarafından büyük bir köpek resmi çizilip bu resme tapıldığı bilgisi mevcuttur. Bu bilgi, Sirius Yıldızı'nın gökyüzündeki en parlak gününün 18 Şubat olduğu bilgisi ile beraber düşünüldügünde bu köpek çizme töreni ile Sirius arasında bir bağlantı olduğu söylenebilir. Çin tarihi kaynaklarında köpek başlı insanlar ile ilgili bir bilgiye daha rastlanmaktadır. MS 506'da Han sülalesi hükümdarlarından Thangen'in imparatorluğunun beşinci yılında, Phuan ülkesinde bir adam deniz seferindeyken rüzgarın sürüklemesi ile bir adaya düşer. Sahile çıkarken Orta Çin halkına benzeyen adamlar görür; fakat dillerini anlayamaz. Bu adamların vücutları, insan vücudu ama kafaları, köpek kafası şeklindedir (Candan 2002, 88). Çin efsanelerinde sıklıkla kutsal adalardan bahsedilir; imparatorlar bu adaları bulmak ve ölümsüzlüğü elde etmek için uğraşır. Bu kutsal adalardan birinde vücudu kıllarla kaplı beyaz kadınların bulunduğu bir ülke vardır. Bu kadınlar, ilkbahar mevsiminde yıkanmak için nehre girer ve hamile kalırlar. Kocalarının başları köpek başı şeklindedir ve onlar, köpek havlaması gibi sesler çıkartmaktadır (Mackenzie 1996, 103).

Sirius izlerine rastlanılan bir diğer mitoloji de Hint mitolojisidir. Çok geniş ve karışık bir mitolojiye sahip olan Hintlilerin en eski ve temel kaynakları Vedalardaki tanrılar ve kahramanlar, inanç sistemleri değiştikçe şekil ve isim değiştirmeye başlamıştır. Bu da büyük bir karışıklığa sebep olmuştur. Bir tanrının birden çok ismi ve lakabı mevcuttur. Hint mitolojisinde Sirius ile yakından ilişkili olduğu düşünülen tanrı, Şiva'dır. Şiva fırtına, şımşek, yangın gibi yıkıcı felaketlerin kişileştirilmiş tanrısıdır. Şiva, ebedi zamandır. O, her şeyin yaratıcısı, sabitleyicisi ve yok edicisidir. Evrendeki devreleri ve ritimleri düzenler (Emmanuel 1995, 8082). Şiva'nın adı aslında Vedalarda "Rudra" olarak geçmektedir; bu nedenle ona "Şiva-Rudra" da denir (Kaya 1997, 149). Şiva'nın adlarından biri de "Íśvara / İswara" (Yüce Efendi)'dır. İ́vara / İşwara, Sanskritçede "ok" ve "ışık ış̧ıı" manasına gelen "işu"dan türemiştir. "İşvasa" ise "yay" ya da "okçu” demektir. İ́vara / İşwara, "ok”tan türemiş ve "yüce efendi" manasını kazanmış bir kelime ise ve bu kelime, bütün evrende tek olan ilahi okun sahibi Şiva-Rudra'y1 işaret etmekte ise bu, Şiva-Rudra'nın Sirius ile ilişkili olabileceği konusunda bir ipucu niteliğindedir. Hinduizmdeki beş uçlu yıldız da Şiva-Rudra ile ilişkilendirilmiştir ki beş uçlu yıldız ile de genellikle mitolojilerde Sirius işaret edilmektedir (Salt \& Çobanlı 2001, 68). Bir de Rudra'nın "rud” yani “bağırmak, ulumak" kökünden geldiği bilinmektedir. Buradaki "ulumak”, Sirius ile bağlantılı kurt ya da köpek motifini çağrıştırmaktadır (Campbell 1998, 248). ŞivaRudra, av hayvanları avcısı ve evcil hayvanların efendisidir. Av hayvanları avcısı Sanskritçede "mrgavyadha" (vahşi hayvanları delip geçen) şeklinde karşl1ık bulmuştur; bu sözcük aynı zamanda Sirius Yıldızı'nın Sanskritçedeki karşılı̆̆ıdır (Bonnefoy 2000, 666). Bu durumda ŞivaRudra ile Sirius ilişkisine kesin gözüyle bakmak mümkündür. Şiva-Rudra ve Sirius ile ilişkili olan ok-yay motifi, Hint mitolojisinde birçok mitte yer almaktadır.

Vedalarda Şiva-Rudra'nın "Marutlar" adı verilen oğulları olduğu yazmaktadır. Soyut bir tanrı olan Diti, İndra'nin şimşeği ile "49" parçaya bölünmüş ve İndra her bir parçayı bir Marut haline getirmiştir. Marutlar aynı yaşta, aynı akıl seviyesinde, aynı yerde yaşayan bir tanrı grubunu oluşturur. Onların yaşadıkları yere "Māruta" denilmektedir. Altın gibi 1şıltılı, ateş gibi parlak Marutların lakapları "ristividyut” (parlayan şimşek)'tir (Kaya 1997, 99-100). Sayılarının "49" olması ile Sirius A ve Sirius B'nin yörünge hareketinin “49" yılda tamamlanması arasında; onların ne kadar parlak olduğundan özellikle bahsedilmesi ile Sirius A'nın en parlak yıldız olması arasında ilişki kurmak mümkündür.

Hint mitolojisinde ateş tanrısı olan Agni’nin bir başka tanrıda kendini gösterdiği şekli olan 
Brihaspati'nin ok ve yay taşıması dikkat çekicidir ve Sirius ile ilgili yeni bir ipucu niteliğindedir. Agni'nin sembolü, tıpkı Eski Mısır'da İsis'in sembolü gibi, üçgendir. Üçgen Hint inanışında, tesirin semavi alemden yeryüzüne ve insanlara inişini temsil etmektedir (Salt \& Çobanlı 2001, 347). Vedalarda "Gāndīva" adında ünlü bir yaya sahip olduğu anlatılan Agni'nin "49" ateş çıkarttığından ve bu "49" kozmik ateşin yansımalarının insan varlığında geliştiğinden bahsedilmektedir. $\mathrm{Bu}$ ateşler tam olmadan insan varlığının mükemmelleşemeyeceği belirtilmektedir. Bu "49" kozmik ateş, sayı ve göklerden gelmesi itibarıyla Sirius A ve Sirius B'nin birbirleri etrafındaki yörünge dönüş sürelerine eşit görünmektedir. " 49 " y1llık yörünge tamamlama sürecinin, Hint inanışında insanı mükemmelleşmeye doğru götüren süreç olarak "49 kozmik ateş" şeklinde Agni üzerinden anlatılmış olması mümkündür. Kendini görünmez yapma özelliğine sahip olan Agni (O’Flaherty 1996, 88) aynı zamanda birkaç mitte "uyumaya gitti ve ortadan kayboldu" şeklinde geçmektedir (Bonnefoy 2000, 1007). Bu ipucu da Sirius A'nın yetmiş günlük kayboluşundan sonra Güneş'in doğuşuyla aynı zamanda tekrar görünür hale geldiği helyak doğuş ile Agni'nin kaybolup veya uykuya gidip bir süre gözükmedikten sonra tekrar ortaya çıkması arasında bir ilişki olabileceğini düşündürür ve eğer Agni ile Şiva-Ruda aynı tanrı ise bu ipucu gerçekten Sirius'u işaret etmektedir. Agni aynı zamanda ölen kişilerin cesedini, ataların ve tanrıların dünyası olan öbür dünyaya götürmekle görevlidir (Kaya 1997, 113). Eski Mısır'da bu görevi, yine Sirius ile yakından ilişkili olan, öbür dünya ile bu dünya arasında elçi olduğu düşünülen, ölenlerin ideal yol arkadaşı çakal / köpek başlı Anubis yerine getirmektedir.

Hint geleneklerinde Sirius, Samanyolu'nun bekçisi köpek Sarama'dır. Sarama hakkında çok fazla bilgi bulunmamaktadır. O, Rig Veda'da adı geçen “göksel köpek”tir. İndra’yı koruduğu ve onun habercisi olduğu bilinmektedir. İblisler tarafindan çalınan, insanlık için süt sağlayan ilahi inekleri kurtarması ile ünlüdür. Bu köpeğin iki oğlu vardır. Onlara "Sarameyalar" (Sarama'nın yavruları) denir. Bu köpekler de ölüm tanrısı ve kanunların lordu Yama'nın koruyucularıdır (Kaya 1997, 139). Sarama'nın aslında "dharma” olduğu düşünülmektedir (Bonnefoy 2000, 730); çünkü Puranalarda tüm yırtıcı hayvanların annesi olduğu belirtilen Samara'nın, Mahabharata'da İndra tarafından cennete kabul edildiği ve burada dharmaya dönüştüğü söylenmektedir. Dharma, dünyanın toplumsal, ülküsel düzeni demektir; olması gereken erdem ve dürüstlük bilgisini içerir (O’Flaherty 1996, 294).

\section{Türk Mitolojisinde Sirius İzleri}

Siriusyen kültürün Türk mitolojisindeki ipuçlarına ulaşabilmek için araştırılması gereken unsurlar, yukarıda ele alınan dünya mitolojilerindeki örneklerden hareketle "gök tanrl", "lşlk", "ylldız", "ok ve yay", "kurt ve köpek” olarak tespit edilmiştir.

Sirius inanmalarına göre tanrılar göktedir ve Sirius'tan medeniyetlere gönderilen elçiler de gökten gelmektedir. Türkler için gök, sonsuzluğun işareti olan ve kutsal yaratıcı tanrının bulunduğuna inanılan bir mekandır. Araştırmacılara göre, gökte bulunan yaratıcı tanrıya olan inanç, Gök Tanrı dininin oluşmasını sağlamıştır. Türklerin Gök Tanrısı; Türklere yardım eden, onları ödüllendiren veya cezalandıran, adaletli bir tanrıdır. Bu tanrı Hellen, Roma veya Mezopotamya tanrıları gibi insanoğlu ile doğrudan temasta bulunmaz; onun elçileri, temsilcileri vardır. Gök Tanrı, bu elçiler ile Türk hükümdarlarına "kut” gönderir. Kut sahibi hükümdarlar "tanrı oğulları" olarak kabul edilir ve Gök Tanrı'nın yeryüzündeki tecellisi olarak davranmaya başlar. Onlar, bu kut sayesinde halkları için en doğru kararları verip ülkelerini başarıyla yönettikleri takdirde yeryüzünün sahibi olmaya hak kazanır. Çin kaynaklarından elde edilen bilgilere göre Hun imparatoru Mete'nin unvanı “tanrının oğlu”dur. Mete'nin, Oğuz Kağan destanının kahramanı olduğu düşünülmektedir. Oğuz Kağan Destanı'na bakıldığında Oğuz 
Kağan'ın da Tanrı tarafından olağanüstü şekillerde gönderilen iki eşinin elçiliğiyle Tanrı'dan kut aldığ1 ve bu kutu kaybetmemek adına yeni yerler fethederek halkına nizamı ve töreyi öğrettiği görülür. Diğer bir Hun imparatoru olan Künçin de başarılarının Gök Tanrı'nın işi olduğunu; kendisini tuzaklardan Tanrı takdir buyurduğu için kurtarabildiğini söylemiştir (Kafesoğlu 2007, 38). Göktürkler, kendi devletlerinin kurulmasının Gök Tanrı'nın isteği ile olduğunu Orhun yazıtlarında belirtmiştir. Bu yazıtlarda, Göktürklere zafer kazandıranın ve onları felaketlerden koruyanın da yine Gök Tanrı olduğu yazılıdır (Çoruhlu 2006, 19). Bilge Kağan yazıtında "Kut'um olduğu için kağan oldum" ifadesi mevcuttur. Yazıtlarda Bilge Kağan'ın babası İlteriş Kağan'ın ve annesi İl-Bilge Hatun'un da Türk budunu yok olmasın, hür ve müstakil olsun diye Tanrı tarafından yükseltildikleri ifade edilmiştir (Günay \& Güngör 2007, 61-62). İşbara Kağan'ın Çin'e yazdığı bir mektupta unvanı “Gökte doğmuş, büyük Göktürklerin ve bütün dünyanin bilge ve mukaddes imparatoru" şeklindedir (Ögel 1982, 58).

Sirius'a işaret eden varlıkların genellikle bir ışık ile birlikte tasvir edilmelerinin Türk mitolojisindeki benzer örneklerini bulabilmek için "1şık" unsuruna bakıldığında bu unsurun Türk mitolojisinde geniş yer tuttuğu göze çarpar. Yaratılış destanında, Tanrı'ya yaratma ilhamı veren Ak Ana, 1şıklı hatta 1şıktan bir kadın hayalidir (Banarlı 2001, 30). Türk kahramanlarından Alp Er Tunga'nın, İranlıların düşmanı olan Zini Gav'ı öldürmesi üzerine "Altun Yaruk" denilen 1şık, kahramanın üzerine inmiştir (Uraz 1967, 67). Doğduğunda yüzü “gök” olan Oğuz Kağan'ın eşlerinden ilki, gökten inen 1şıkla gelen ve alnında parlak bir beni olan tanrı elçisidir. Oğuz Kağan'ın bu eşi ve bu eşinden olan çocuklarının gökyüzüne işaret eden isimlere sahip olması (Gün Han, Ay Han ve "Yıldız" Han), Türklerin göğe verdiği önemi belirtirken gök ile ilişkili farklı bir şeyler anlatmak istedikleri düşüncesini de uyandırmaktadır. Gün Han, Ay Han ve Yıldız Han, gökten gelen tanrıların veya tanrı elçilerinin "ilahi gen"ine sahip çocuklardır. Onlar, Türklerde gökyüzünün hakimi olma sembolü olan "yay"a sahip olan ve bu bakımdan da yeryüzünün hakimi olan devletin yönetiminde ilk olarak söz hakk1 sahibi olacak olan çocuklardır. Oğuz Kağan'ın ağaç kovuğunda oturan ve "gözü gökten daha gök” olan ikinci eşi de yine Gök Tanrı'nın yeryüzündeki elçisidir. Türklerin ilk önce gögün sonra da yerin yaratıldığına olan inancının bir göstergesi olan bu eşten doğan çocuklar da ilahi gene sahip olmakla birlikte onların isimleri de, Türklerin kutsallık atfettikleri üç simgeye işaret etmektedir (Gök Han, Dağ Han, Deniz Han). Oğuz Kağan'ın, seferleri sırasında çadırına giren bir “ışık” ile gelen gök tüylü gök yeleli kurdu da hem 1şı motifinin hem de kurt motifinin Türk mitolojisindeki en önemli örneğidir. Uygurların Türeyiş Destanı'nda Toğla ve Selenge nehrinin arasında bulunan iki ağacın üzerine bir gün gökten bir "ışı k" iner ve halk, ilk inişinden sonra bu 1şığın her gece tekrar indiğini fark eder. Bir gün 1şıkların bulunduğu yerde beş çocuk bulan halk hemen bu çocuklara "hükümdar oğulları" gibi saygı gösterir ve onları besleyip büyütür. Tanr1 tarafından hükümdarlık için gönderildiğine inanılan bu beş çocuktan Bökü Tekin, han olarak seçilir ve ülkeyi başarıyla yönetir (Sakaoğlu \& Duymaz 2002, 211-212).

Gök, ışık ve Sirius söz konusu olunca Türk mitolojisinde yıldızlar ile ilgili inançlar ve anlatmalar da önem kazanmaktadır. Diğer medeniyetlerde olduğu gibi Türklerde de astrolojiye önem verilmiştir. Özellikle de yaşadıkları göçebe hayat onları göğün hareketlerini ve yıldızların konumlarını inceleyerek hareket etmeye sevk etmiştir. Hunların bir işe başlamadan önce ayın ve yıldızların durumuna baktıkları bilinmektedir (Günay \& Güngör 2007, 71). Daha çok yedi gezegen yıldız (Ay, Utarit / Merkür, Zühre / Venüs / Çoban Yıldızı, Güneş, Mirrih / Merih, Müşteri / Jüpiter ve Zühal / Satürn) hakkında inanışlara sahip olan Türklerde birebir Sirius Yıldızı ile ilgili bir anlatmaya rastlanmamaktadır. Yalnız Bonnefoy'un editörlüğünü yaptığı Mitoloji Sözlügü'nde Türkler ve Sirius Yıldızı ile ilgili şu bilgi verilmiştir: “ ... Sirius, 'Beyaz Aygır'dır ... Bazı yıldızlara 'tapılır' ya da 'derin saygı duyulur'. Özellikle Sirius'a (Kaynaklar 
Türklerin ona 'tanrlların tanrısı' adını verdiklerini söylemektedirler), İkizler'e, Satürn'e ve doğal olarak Ay'a ve Güneş'e” (Bonnefoy 2000, 343). Bu bilgi önemlidir; çünkü bu bilgiye göre Türkler ile ilgili henüz ulaşılamamış, bilinmeyen kaynaklarda Sirius adı önemli ölçüde geçmektedir. Kimi araştırmacılara göre Türk mitolojisinin en önemli yıldızı kabul edilebilecek olan Kutup Yıldızı'na verilen "Demir Kazık” ismi, bilinmeyen bir dönemde Sirius için kullanılmıştır. Tümüyle yoğun demirden oluşan Sirius B Yıldızı'nın varlığından haberdar oldukları düşünülen Şamanist Türklerin Sirius'a sonradan "Ak Yıldız" demeye başladıkları; aslında "Ak Ylldız"ın da önceden Venüs için kullanıldığ 1 iddia edilmiştir (Salt \& Çobanlı 2001, 395). Şamanist Türklerin inancına göre Demir Kazık Yıldızı, "tanrının gönderdiği elçi” ile şamanın iletişim kurabildikleri kapıdır; şaman bu kapıdan geçip yukarı çıkamaz, elçi de bu kapıdan geçip aşağı inemez. Onlar tam bu noktada konuşur ve geri dönerler.

Sirius ile alakalı bir diğer sembol olan "ok ve yay", avcı ve akınc1 Türklerin mitolojisinde sayg1 duyulan, kutsal bir unsur olarak bilinmektedir. Oğuz Kağan Destanı'nda geçen şu bölümler Türklerin ok ve yaya verdikleri kutsiyetin eşsiz ifadeleridir: “... Günlerden bir gün uykuda bir altın yay ve üç gümüş ok gördü. Bu altın yay gündoğusundan ta gün batısina kadar ulaşmıştı ve ü̧ gümüş ok da şimale doğru gidiyordu. ... 'Benim gönlüm avlanmak istiyor. Ihtiyar olduğum için benim artık cesaretim yoktur; Kün, Ay ve Yultuz, doğu tarafina sizler gidin; Kök, Tă̆ ve Tengiz, sizler de batı tarafina gidin.' Ondan sonra üçü doğu tarafina, üçü de batı tarafina gittiler. Kün, Ay ve Yultuz çok av ve çok kuş avladıktan sonra yolda bir altın yay buldular; onu aldılar ve babalarına verdiler. Ŏguz Kağan sevindi, güldü, yayı üçe böldü ve 'Ey büyük (oğullarım), yay sizlerin olsun; yay gibi oklarl göğe kadar atın.' dedi. Kök, Tă̆ ve Tengiz çok av ve çok kuş avladıktan sonra yolda ü̧̧ gümüş ok buldular; aldılar ve babalarına verdiler. Oğuz Kağan sevindi, güldü, okları üçe üleştirdi ve 'Ey küçük (oğullarım), oklar sizlerin olsun. Yay oku attl; sizler de ok gibi olun.' dedi. ...” (Bang \& Arat 1936, 29-31). Oğuz Kağan'ın vezirinin rüyasında gördüğü bu ok ve yay, devletin geleceği için önemli gelişmelerin gerçekleşeceğine; Oğuz Kağan'ın devletinin, dünyanın sahibi olacak olan devlet olacağına ve Oğuz Kağan'ın yerini artık çocuklarına bırakabileceğine işarettir. Sirius ile ilgili olarak düşünüldüğünde ise, Sirius A ve Sirius B'nin birbirleri etrafinda yaptıkları yörünge hareketinin ok ve yay ile temsil ediliyor olması ve diğer mitolojilerdeki anlatmaların da Sirius'u kastederek "ok ve yay"dan bahsetmesi, Oğuz Kağan'da geçen ok ve yayın Sirius ile ilgili olduğunu gösterebilir. Ok ve yay Türkler için bir "dünya hakimiyeti” ve bir "dünya devleti” sembolüdür (Ögel 1982, 39). Yay tek başına, Türklerde gök kubbenin yani göğün ve hakimiyetin sembolüdür. Yayın sahipleri gün doğusundan gün batısına kadar göğün kapsadığı bütün alanların da sahipleri olacaktır. Oğuz Kağan Destanı'nda Gün Han, Ay Han ve Yıldız Han (BozOklar) bu yayı bulmakla birlikte Gök Tanrı'nın yeryüzündeki yeni temsilcileri olmuşlardır yani onlar yeryüzünün yeni hükümdarları, dünya devletinin yeni sahipleridir. Kut onlara, tıpk1 babaları Oğuz Kağan'a gelişi gibi, Gök Tanrı'dan gelmiştir. Babalarına iki kadın elçi ile gelen kut Gün Han, Ay Han ve Yıldız Han'a, Sirius'un en belirgin sembollerinden biri olan yay ile gelirken yayın ayrılmaz parçası olan ok ile de Gök Han, Dağ Han ve Deniz Han'a (Üç-Oklara) Gök Tanrı'nın elçileri oldukları iletilmiştir; çünkü ok, Türklerde elçiliğin sembolüdür. Artık Oğuz Kağan'ın bu üç küçük oğlu, Gök Tanrı'nın hem kendisi için hem de Gün Han, Ay Han ve Yıldız Han (Boz-Oklar) için (hükümdarlık için) görevlendirdiği elçilerdir. Onlar, Türk mitolojisinde "karanlıkların diyarl, gidilmeyen yer" diye bilinen "kuzey"den sorumludur. Kuzeyin üç okuna sahip olan Gök Han, Dağ Han ve Deniz Han'ın birer elçi olduğu ve karanlık olduğu özellikle belirtilen Sirius B'den gelen "tanrı elçileri” unsuru bir arada düşünülürse ok ile Oğuz Kağan'ın üç küçük oğlunun ilişkilerinin Sirius noktasında birleştirilebileceğini fark etmek mümkündür. 
Bir Kırgız efsanesinde yay ve hükümdarlık ilişkisi şu şekilde verilmiştir: "Altın Bel Han'ın

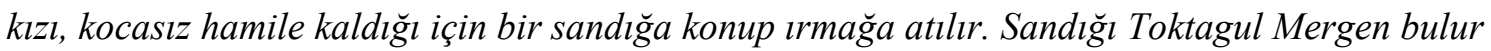
ve sudan çıkarır. Kız, Toktagul'a olanları anlatır. Kızın dört oğlu olur. Bu oğlanlardan Şıngız, atalarını bulmak için ırmağın yukarısına doğru gider. ... Ü ̧̧ kardeşi Şıngız'a karşı gelir. Anneleri de der ki: "Dördünüz de benim oğlumsunuz. Size adil bir yol göstereyim. Yaylarınızı Güneş'in ışılklarına asın. Işık hanginizin yayını tutup yukarı çekerse o padişah olsun. ... Güneşin ışı̆̆l, Şıngız'ın yayını altında bir direk, üstünde asılacak bir yer varmış gibi havada tutar ve Şıngız han olur" (Ögel 2002, 114-115). Öncesinde ve devamında Kırgızların kökenini konu alan bu efsaneden de anlaşılacağı üzere, Tanrı tarafından uygun görülmüş kutsal bir hamilelik söz konusudur ve doğacak çocuk veya çocuklardan biri mutlaka bir kahraman olacaktır. Burada kahraman ve hükümdar rolü Şıngız'a aittir ama önemli olan onun bu rolü bir yay aracılığı ile almış olmasıdır. Tanrının hükümdarlık işareti için yine yayın seçilmiş olması dikkat çekicidir.

Altay, Kazak, Karakalpak, Özbek ve Başkurt Türkleri arasında yaygın bir destan olan Alıp Manaş Destanı'nda destan kahramanı Alıp Manaş, çok iyi bir okçudur ve demirden dağ gibi bir yaya sahiptir. Alıp Manaş'ın yayını kaldırmaya kimsenin gücü yetmez (Çobanoğlu 2007, 228229). Sirius B'nin yoğun demirden olduğu düşünülürse bu destanda kahramanın demir bir yaya sahip olması Siriusyen kültür açısından önemli bir ipucu oluşturabilir.

Altay Türklerinin Er Samır Destanı'nda, karısı Ak Tana'yı Erlik'in elinden kurtarmak isteyen Er Samır, Ak Dağ'a gelir. Dağdan geçit bulamayan Er Samır “demir yay"ını çıkarıp "demir ok"una vurur; nişan alıp heybetli dağa gönderir. $O$ an gökyüzü kapanır, yeryüzü görünmez olur. Ak Dağ yıkılıp yerle bir olur ve Er Samır'a böylece yol açılır. Destanın ilerleyen bölümlerinde bu sefer de kardeşi Katan Mergen'i arayan Er Samır, yolda bir kadından kardeşinin Erlik Bey'in yanında, yeraltında olduğunu öğrenir. Er Samır bir delikten yeraltına iner. Orası kapkaranlıktır. Cebinden iki küpe çıkartır ve atının kulaklarına takar. O anda " $A y$ 'ın ve Güneş 'in ışı̆̆ı gibi altın bir ışık” ile Er Samır'ın yolu aydınlanır. Erlik'in kapısına varan Er Samır kapıda biri altı, diğeri sekiz gözlü iki köpek görür. Bu destanda demir ok ve demir yay ilişkisi haricinde, Ay ve Güneş gibi 1şıklı iki küpe için, Sirius B'nin ak cüceye dönüşmeden önce sahip olduğu tahmin edilen yoğun ışığının Güneş'in ışığına benzetilmesi ile de bir ilişki kurulabilir. Ayrıca burada köpek motifi de görülmektedir; fakat burada köpek, Erlik'ten dolayı olumsuz bir roldedir. Yine de "bekçi" olarak Erlik'in kapısında durması, Türk mitolojisinde köpeklerin daha çok Tanrı tarafından bekçi olarak görevlendirilmelerini hatırlatmaktadır.

Maaday Kara, Kan Sulutay, Ölöştöy, Alday Buuçu, Huban Arı̆̆, Aran Taycı ve Er Sogotoh gibi Güney Sibirya sahas1 Türk destanlarında "kastak", "hosto", "albın-cilbin kıybır ok", "kanattu ok" ve "tındu ok" gibi sihirli oklardan bahsedilir. Özel malzemelerden yapılan bu olağanüstü oklar, aşırı ağırdır ve onları sadece destan kahramanları hareket ettirebilir. Bu okların, göksel güçlerin elinde şekillendiği belirtilir ve okları destan kahramanına ya bu göksel güçler ya bizzat Tanrı ya da aile bireylerinden biri verir. Kahraman tarafindan yeryüzünde, gökyüzünde ve yeraltında çeşitli engelleri aşabilmek için kullanılan bu okların ayrıca haberleşme amaçlı kullanıldığı da görülür; kahraman bu tür bir oka mektup bağlayıp onu, haberleşmek istediği kişiye gönderir (Uluışık 2015, 128-129). Okların yapımı, ağırlığı, kullanılış şekli ve yeri, ilahi güç ile olan ilişkisi gibi unsurlar ile Siriusyen kültürle ilişkili olduğu düşünülen anlatılardaki unsurlar arasındaki benzerlik açıktır.

Karaçay-Malkarlara ait Nart destanlarında yer alan kahramanlardan Debet, göğün ve yerin oğludur. O sadece bir kahraman değil aynı zamanda Nartların da ilk demircisidir. Demirin dilini bilir ve ona şekil verir. Kızgın demiri çıplak elleri ile döverek kolayca işler. Oku ilk defa Debet 
yapmıştır. Onun yaptığ 1 ok ve diğer savaş aletleri meteor (gök taşı) alaşımlıdır. Debet'in ölmediği, gökte yaşadığı ve demircilik yaptığı anlatılır. Geceleyin gökyüzünde bir yıldızın kaydığı görülürse bu kayan yıldız, Debet'in gökyüzündeki atölyesinde demir döverken çıkardığ 1 kıvılcımlardır, denir (Adiloğlu 2007, 202-203). Debet'in bir demirci olması ilk olarak Sirius B'nin yoğun demir yapısı ile ilgili bir ipucu olarak kabul edilebilir. Okun mucidi olarak gösterilen Debet’in "yerin ve göğün oğlu" olması da birebir tanrı ile ilişkili bir kahraman olduğunun göstergesidir. Ölmemesi, gökyüzüne çıkıp orada yıldızların arasında, görülmeyen bir yerde yaşaması fakat yaşadığı yerin neresi olduğunun belirtilmemesi de yine Sirius için (özellikle Sirius B için) birer ipucu niteliğindendir.

Şamanizm üzerine yapılan araştırmalar ok ile yayın Şamanist Türkler için farklı bir öneme sahip olduğunu gösterir. Şaman, kötü ruhları kovarken hep ok ve yay kullanmaktadır. Altay şamanlarının "yebe" (dokuz ok) ve "ya" (yay) dedikleri savaş aletleri omuzlarından hiç eksik olmaz; çünkü onlar, bu dokuz okun ve yayın "Kudaydan tartkan" (Tanrı'dan uzatılan) olduğuna inanmaktadır. Bu şamanların yay ile fal baktıkları ve yağmur yağdırdıkları da bilinmektedir. Şaman davullarındaki ok, yay ve yıldız tasvirleri, ayrıca bu davullarda kullanılan demir parçalar (çıngıraklar), davulun iç kısmına yerleştirildiği görülen ok ve yay; şaman kıyafetlerindeki demir ögeler vb. de Sirius inanmalarına ilişkin işaretler olabilir. Buna ek olarak ok ve yayın, özellikle Altay ve Şor Türklerinde yeni doğmuş çocukların beşiklerine Umay'ın sembolü olarak asıldığ görülür.

Altay ve Sibirya efsanelerinde göğe atılıp tanrıya giden oklardan da bahsedildiği görülürken Minusinsk Tatarlarının efsanelerinde demirden yapılmış fevkalade bir yaydan ve o yayın sahibi olan, dünyanın öbür ucundaki kutsal okyanusta (Akdeniz'de) oturan "Demir Yaylı Ak Han"dan da sıkça söz edildiği dikkati çeker (Ögel 2003, 322-323). Yakut Türklerinin Er Sogotoh isimli destan kahramanının ise Sirius ile ilişkilendirilebilecek mavi kurt kürkü bir abaahı vardır. "Mavi”, Sirius'un rengine; "kurt" da Sirius'un sembolüne bir gönderme olabilir. Ayrica bu kahramanın "altı kişinin açamayacă̆ı boynuz yaylı, balıkçının ă̆aç evi kadar büyük oklu" silahları vardır. Attığı oklar ile taş dağı deler. "Demir" ağaçlı ormanda da yoluna okunun yardımı ile devam eder (Çobanoğlu 2007, 183-184).

Türk mitolojisinde Gök Tanrı'nın ilahi gücünü yeryüzüne iletmek ile görevli elçilerinin arasında Siriusyen kültür ile yakından ilişkili olan varlıklar mevcuttur. Bunların en bilineni, “Gök Tanrı'nın yeryüzüne inme ihtiyacı duyduğunda suretini tercih ettiği varlı”" (Aslan 2010, 75) olan kurttur. Türk mitolojisi, içerisinde kurdun adının geçtiği birçok anlatmaya sahiptir. Onlara ait Çin kaynaklarında yer alan bir kurttan türeme efsanesi mevcuttur: Ögel'in anlatımına göre Kao-çı kağanının ancak tanrıyla evlendirmeye layık gördüğü iki kızından biri, tepeden inen ve kızın tanrı olduğuna inandığı kurtla evlenir ve Kao-çı halkı bu evlilikten türer (Ögel 2003, 17-18).

Barındırdığı motifler açısından Sirius ile ilgili inanmaları kanıtlayabileceği gözlemlenen Oğuz Kağan Destanı'nda, Oğuz Kağan'ın yol göstericisi olan “gök tüylü gök yeleli” bir kurt ile karşılaşılmaktadır. Destanda anlatılan göklerden gelen bu yol gösterici kurdun, tanrısallığın simgesi olan renge sahip olması ve gökten inen bir ışık içerisinde bir anda çadırda gözüküp dile gelerek Oğuz Kağan'a yol göstermek istemesi, kurdun gök ile birebir ilişki içerisinde ve tamamen tanrısal vasıflarla donanmış olduğunu göstermektedir. Oğuz Kağan gibi bir kahramanın ordularına yol göstermesine izin verdiği ve kurt durduğu zaman Oğuz Kağan ve güçlü ordusunun da durduğu düşünüldüğünde bu kurdun ilahi bir mesaj taşıdığı sonucu ortaya çıkmaktadır; aksi takdirde tanrıdan kut bulmuş Oğuz Kağan, bir kurdun kılavuzluğuna ihtiyaç duymayacak bir kahramandır. Siriusyen kültürde Sirius'un kurt ile temsil edildiği, Sirius'a 
yoğun bir ışık ile anlatılmalarda yer verildiği, Sirius'un genel itibarıyla mavi renk (gök rengi) ile tasvir edildiği, tanrı elçilerinin Sirius'dan gönderildiği ve bu elçilerin halka yol gösterici ve yardımcı bir rol üstlendiği anlatmaktadır. Bu durumda Oğuz Kağan'ın ok ve yayından sonra bu kurt ile de Sirius kültürü ile ilişkili olabileceğini söylemek mümkündür.

Göktürklerin de, özellikle "boz" renkli olduğu belirtilen ve ondan türediklerine inandıkları bir kurt mevcuttur. Bozkurt destanında bütün halkı öldürülen, kendisi de kolları ve bacakları kesilerek bir bataklığa atılan; fakat bir dişi kurt sayesinde kurtulan bir çocuktan bahsedilir. Dişi kurt bu çocuğu besleyip büyütür ve bir süre sonra onlar karı koca gibi yaşamaya başlar. Ögel'e (2003, 22-23) göre Göktürk Devleti'ni kuran A-şi-na ailesi, bu çocuklardan birinin soyundan gelir. Göktürklere ait Asena Destanı'nda da kurttan türeyen bir çocuktan bahsedilmiştir (Ögel 2003, 27-28). Burada çocuğun kurttan türemesinin anlatıldığı ayrı bir bölüm yoktur; bu çocuğun ne şekilde doğduğu bilinmemektedir. Fakat çok önemli bir noktadan bahsedilmiştir ki bu çocuk "tabiatüstü güçler"e sahiptir. Tanrı elçisinden aldığg ilahi gene sahip çocuk, yağmura ve rüzgara emretmektedir ve tanrıların kızları ile evlidir. Tanrı kızları ile evlenmek, kutsiyetin bir göstergesidir. Bu noktada, daha önce incelenen mitolojilerde tanrı kızları ile evlenen tanrı oğullarından veya tanrı kızları ile evlenen insanoğullarından Sirius ile ilgili olarak bahsedilmesi dikkat çekici bir boyuta ulaşır.

Göktürklere ait Ergenekon Destanı da yine "bozkurt”tan bahseden bir destandır. Burada bozkurttan türeme söz konusu değildir; Oğuz Kağan Destanı'ndaki gibi yol gösterici bir bozkurttan bahsedilir. Destanda Sirius açısından önemli olan sadece kurt değildir; ayrıca eritilen dağın "demir" olması da yine Sirius B'nin yapısındaki maddenin yoğun demir olarak tanımlanmasını çağrıştırmaktadır. Göktürkler, demircilikte usta sanatçılara sahiptir ve onlar demire "kök-temür" demektedir. Bu, Türklerin demiri gök ile bağlantılı gördüklerinin ve ona bir kutsallık atfettiklerinin işaretidir.

Kurdun yol göstericiliğini anlatan Türk efsaneleri, Başkurt Türklerinin anlatmaları ile devam eder. Birçok anlatmada yolda karşılaşılan bir kurt, Başkurtların atalarını verimli topraklara götürür. Başkurtlar hem bir kurt önderliğinde yeni yurtlarına vardıkları için hem de buralarda baş tuttukları için onlara "Başkurt" denilmeye başlanır (Başkurtlara ait bu anlatmalar için bk. Süleymanov 2001, 415-419, 463; Sakaoğlu \& Duymaz 2002, 81).

Kırgız Türklerine ait, bozkurt etrafında şekillenen değişik bir efsane mevcuttur. Bu efsaneye göre eskiden Kırgızların, Karakan adındaki baş atalarından Oğuzkan adlı bir oğlan doğar, onun da yirmi dört tane erkek çocuğu olur. Bu yirmi dört çocuk bir gün oynarken bir bozkurda rastlar. Bozkurt çocukların kendisini öldürmek istediğini hisseder, Tanrıya yalvarır ve gökten şiddetli bir yağmur yağdırır. Yağmur suları birikip sele, sel de tufana dönüşür. $\mathrm{O}$ yirmi dört çocuktan sadece biri kurtulur. O kurtulan çocuğa "Kıroguz" adı konulmuştur. $\mathrm{Bu}$ isim daha sonra “Kırgız”a dönüşmüştür (Akmataliyev \& Kırbaşev 2001, 167). Kırgızlara ait bir başka kurt efsanesi de şöyledir: "Eski zamanlarda bir insan, bir inde insan çocuğunu emzirmekte olan bir kurt görür. İnsan oraya yaklaşınca kurt kaçar. Kurdun emzirdiği çocuğu yanına alıp götüren insan, onu büyütür ve ona "Kaba" adını verir. Kaba'nın saçları kurt yelesi gibi dimdik durur (Başka bir varyantta, Kaba'nın boynundan kuyruk kemiğine kadar yelesi vardır). Bu nedenle ona "Yeleli Kaba" denilmeye başlar. Kırgızların Kaba boyu, bu Yeleli Kaba'dan türemiştir." (Akmataliyev \& Kırbaşev 2001, 155). Bir Kazak-Kırgız efsanesi olan ve Radloff tarafından tespit edilen "Dudar Kız" efsanesinde ise doğar doğmaz konuşan kutlu bir kıza bir türlü isim konulamaz. En sonunda kızın adını bir kurt koyar. Bu nedenle de kız, bu kurt ile evlenir (Ögel 2002, 117).

Karaçay-Malkar Nart destanları üzerine yapılan araştırmalarda, "Kurdalagon” ve "Ala 
ugan" isimleri ile karşılaşılmış ve bu isimlerin etimolojik çalışmaları yapılmıştır. Bu çalışmalara göre "kurd", "demirci”; “alag” ise "bir Nart sülalesi"dir ve bu çalışmalar, demirci Debet'in başlangıçtaki adının "Alogan” veya "Al-Ogan" olduğu; daha sonra Musevi kültürünün etkisi ile Davut peygamberden dolayı bu ismin Debet'e dönüştügü fikirlerinin ortaya çıkmasına sebep olmuştur (Adiloğlu 2007, 205). Destana göre Debet'in oğlu Alavgan, dev gibi iri yapılı ve çok kuvvetli bir kahramandır. Adilhan Adiloğlu'nun Karaçay-Malkar Nart destanları üzerine yaptığ1 etimolojik çalı̧̧malarda ise "Alagan", "Alagların kurt soyundan demircisi” veya "Kurt soylu Alagan" şeklinde izah edilmiştir ve "Kurt Alagan" ile "bozkurt"un işaret edilmek istendiği belirtilmiştir (Adiloğlu 2001, 29-32). Demirci Debet, Adiloğlu'nun çalışmasına göre hem kurt soyundandır hem de okun mucididir; oğlunun adı da kurt soyundan olduğu için Alagan'dır. Adiloğlu'nun bu etimolojik çalışması, Sirius ile ilişkilendirilebilecek ipuçlarını bir arada görme imkanı vermektedir. Karaçay-Malkar Nart destanları içerisinde Örüzmek isimli, akıllı oluşu ve ağırbaşl11ı̆̆ ile tanınan bir kahramandan daha söz edilmektedir. Nart kahramanlarının lideri olan Örüzmek' in doğuşu şöyle ifade edilmiştir: "Demirci Debet, günlerden bir gün dağlarda demir madeni ararken gökten bir meteorun düştügünü görür. Meteorun düştüğü yerde derin bir çukur, çukurun içinde de küçük bir çocuk görür. Çocuk çukurun içinde dişi bir kurdu yakalamış ve onun sütünü emmektedir. Debet bu çocuğu alıp Nart ülkesine götürür" (Adiloğlu 2007, 208). Gökyüzü ile ilişkisi olduğu bilinen demirci Debet'in çukurda gördüğü çocuk ve kurt, gök ile ilişkili olduklarının belirtilmesi açısından bir meteor düşmesi olayı sonucu ortaya çıkmıştır. Bu da hem kurdun hem de çocuğun kutsal özellikler taşıdığının bir işaretidir. Debet, Alagan ve Örüzmek başta olmak üzere Karaçay-Malkar Nart destanlarının geneline, Siriusyen kültür gibi farklı bir kültür açısından bakıldığında bu kahramanlık destanları, motif hazinesini daha belirgin olarak göstermektedir.

Şamanizmde kurt, Tanrının haber getiricisidir. Tanrıdan insanoğluna kutsallıklar taşıyan kurt ile şaman, trans yolculuğu sırasında karşılaşır. $\mathrm{Bu}$ yolculuk sırasında köpekle de karşılaşabilen şaman için Altay inanışlarında öteki alemdeki aşılması gereken köprünün başında yine bir köpek bulunmaktadır (Salt 2010, 223). Radloff'un Proben 3'ünde yer alan bir Kırgiz baksı duasında demir ruhuna seslenildikten sonra on kurttan bahsedilir ve bu kurtların içinde yer alan “altı ağızlı Gök-Börü”ye seslenilir (Ögel 2002, 116). Tuba Türklerinin bir baksı duasında da, aynı duanın içerisinde kurda hem "gök böri" hem de "boz kurt" şeklinde seslenildiği görülmektedir. Aynı zamanda bu duada seslenilen kurdun, Altay yaratılış destanlarında dünyanın yaratıcısı olduğu belirtilen ve göğün on yedinci katında oturan, Sibirya toplulukları arasında ise göğün yedinci katında oturduğuna inanılan Kayra Han olması da dikkati çekicidir. Duada kurdun "tanrının habercisi” olduğu da vurgulanmaktadır: “... / Yücelerdeki (üstü) Tanrıdan emir getirenim! / Yedi gün yemek yemedim! / Tanrımın yakını! / Gök börü erenim Kayra-Han! / Ăgzını, burnunu yalayan! / Boz kurdum! / ...” (Ögel 2002, 126).

Altay Türklerine ait Maaday Kara Destanı'nda çocuğu olmayan Maaday Kara, aniden ortadan kaybolan Altay halkını bulmak için gittiği yoldan geri döndüğünde mucizevi bir şekilde bir oğlu olduğunu görür. Maaday Kara, olağanüstülükler göstermeye başlayan bu erkek çocuğunu doğaya teslim etme kararı alır. Oğlunu kara dağa bırakır; Altay Dağı'nın sahibesi yaşlı kadın bu çocuğu bulur (Bu kadın daha sonra bu çocuğa Kögüdey-Mergen adını verecektir). Çocuk kadından ilk olarak "demir" kavaktaki küçük kuşları vurabilmesi için "ok ve yay" ister. Ardından ok ile kuşları vurur. Dağın tepesinde duran "yetmiş" tavşanı da bir ok atışı ile vurur. Derken korkunç bir ses duyulur ve yerin sahibi yedi "kurt" ulumaya başlar. Çocuk bu kurtları yok etmek için pusuya yatar ve gizlendiği yerden yedi kurdu da öldürür (Çobanoğlu 2007, 155156). Bu destanın son bölümünde de ilgi çekici bir açıklama görülmektedir: "Gökteki 'Yedi Kağan' adı ile bilinen yedi yıldız, birbirine eş yedi Kögüdey-Mergen'dir. Kutup Yıldızı ise 'Altın 
Küskü'dür. 'Üç Maral' dedikleri takımyıldızının üzerinde duran kırmızı bir yıldız vardır; bu da Kögüdey-Mergen 'in ortadaki maralın karnını yardlğı oktur" (Çobanoğlu 2007, 160). Siriusa ait bütün ipuçlarının aynı anda verilmiş olması, Maaday Kara Destanı'nın Siriusyen kültür açısından bir mesaj taşıdığını göstermektedir. Babasız, mucizevi bir doğumun ardından olağanüstülükler gösteren Kögüdey-Mergen, ilk olarak ok ve yay isteyerek (Sirius A ve Sirius B'nin sembolü) Gök Tanrı-Sirius bağlantısının ilk aşamasını tamamlamıştır. Daha sonra bu ok ve yay ile "demir"den kavaktaki kuşları vurup (Sirius B'nin ağır metali), dağın tepesindeki yetmiş tavşanı (Sirius'un helyak doğuşundan önce gökyüzünden kaybolduğu yetmiş günlük süreç) da bir ok ile öldürmüştür. Bunun hemen akabininde yerin sahibi yedi kurdu (Sirius'u temsil eden hayvan) öldürmüştür. Destan sonunda gökyüzüne yükselen Kögüdey-Mergen'in mekanı yıldızlar olmuş ve o, kırmızı ok şeklindeki yıldıza sahip olmuştur. Yıldızlar ile ilgilenen bilim adamlarının çok eski dönemlerden itibaren, Sirius B'nin bir ak cüceye dönüşmeden önceki halinin (120 milyon yıl önceki halinin) "kızll bir dev" olduğunu söylediklerini burada belirtmek gerekir. Destanda geçen ve bir takımyıldızı ile beraber anılan kırmızı ok, Sirius B'yi işaret etmektedir, demek mümkündür.

Altaylıların Ak Tayçı Destanı'nda da uzun süre çocuğu olmayan ve olan iki çocuğunu da Erlik'in kaçırdığı Altın Topçı ve Ak Bökö'nün ihtiyar yaşlarında mucizevi şekilde bir oğulları olur. Oğluna kundak yapmak için samur avlamak isteyen Ak Bökö ava çıkar ve bu av sırasında kuyruğunun uzunluğu altmış kulaç olan koskocaman bir Ak Kurt ile karşılaşır. Ak Kurt, Ak Bökö'yü yakalar ve onun hayatını bağışlaması için ondan, yeni doğmuş bebeğini kendisine vermesini ister. Ak Bökö çaresiz kabul eder. Çocuk, bu kurdun yanında kara dağdaki sarayda büyür. Kurt, çocuğa Ak Tayçı adını verir. Bir gün atına atlayıp yollara düşen Ak Tayçı'nın yolda yüz gelin ile yüz yiğit sırayla karşısına çıkar (Yolda karşılaşılan yüz gelin ve yüz damat, Sirius A ve Sirius B'nin birbirleri etrafinda yaptıkları yörünge hareketinin toplamı olan yüz sayısını belirtmek için kullanılmış olabilir ki bu, Hellas’ta birbirleri ile evlendirilecek olan Danaos'un kızları ile Aigyptos'un oğullarını ve bu çocukların sayılarının da Sirius A ve Sirius B'nin birbirleri etrafında yaptıkları yörünge hareketinin toplamı olan yüz sayısını verdiğini hatırlatmaktadır). Yoldan geri dönerken de bu yüz gelin ile yüz yiğidin donduğunu görür. Bu arada yetmiş dallı kavak ağacının dibinde sarı saçlı, kara kaşlı bir kız görür. Kızı da yanına alıp saraya gider. Ak kurt, Ak Tayçı'ya bu kız ile evlenmesini söyler. Ayrıca gerçek anne ve babasının da kim olduğunu açıklar. Bunun üzerine Ak Tayçı kızı da alarak ailesini bulmak için yola çıkar. Yol boyunca Temir Kağan ve Erlik Bey, Ak Tayçı'nın peşindedir. Ak kurdun yardımı ile yeraltına inmesi gerektiğini öğrenen Ak Tayçı, zifiri karanlık yeraltını atının kulaklarındaki iki inci küpe ile aydınlatır (Altay Türklerine ait Er Samır Destanı'nda olduğu gibi.) Destanın sonunda Ak Tayçı, Ak Kurt'un gerçek karısını bulup ona getirir ve Ak Kurt, karısının elini tutup silkelenince yakışıklı bir bahadır haline gelir. Bununla birlikte Ak Kurt'un aslında, Altın Topçı ve Ak Bökö'nün Erlik tarafından kaçırılan iki çocuğundan biri olduğu ortaya çıkar (Dilek 2002, 112-171).

Kurt ile ilgili bu makalede verilen örneklerin dışında diğer Türk topluluklarında, Sirius ile ilişkili olabileceği düşünülebilecek mevcut kurt anlatmaları şöyledir: Yakut Türklerinde bir kahramanı emzirerek ödüllendiren bir kurt ilaheden bahsedilmektedir (Salt 2010, 223). Ayrica Yakutlar, kurtların dolunayı yemesi üzerine Ay'ın evrelerinin oluştuğuna inanmaktadır. Kazan Türklerinde, kurtlar tarafından büyütülen çocuğun anlatıldığı bir rivayet mevcuttur (Minnegulov 2001, 395). Çuvaş Türklerine ait anlatmalarda "Bihambar" denilen kurtların hükümdarından bahsedilmektedir (Uraz 1967, 106). Gagavuz Türkleri ise "Büyük Araba Yıldızı" denilen sekiz yıldızlı bir takımyıldızdan bahsetmektedir ve bu yıldızın en önünde arabaya yol gösteren bir yıldızın daha mevcut olduğunu, onun da bir kurt olduğunu anlatmaktadır (Ergun 1997, 785). 
Karaim Türklerinde de köklü bir kurt kültünün olduğundan bahsedilmektedir. Onlarda kurttan türemiş olma inancının yaygın olduğunu söyleyen Yaşar Kalafat bir yazısında, Karaimlerin kendi aralarında sık sık tekrarladıkları "Temelimiz kurttan olmuştur" sözüne de dikkat çekmiştir (Kalafat 1999, 76-83). Radloff'un Güney Sibirya’daki Baraba-Om Türklerinden derlediği bir masalda Kara Kököl adlı bir yiğit silkinir ve altın yünlü bir kurda dönüşür (Ögel 2002, 115116). Yine Radloff'un Kuzey Sibirya'daki Hoca Aul Türklerinden derlemiş olduğu bir masalda kurt, hanın kızını alabilmesi için yiğide yardım eder. Yiğit, bu kurdun yardımı ile "dumbar" denilen kutlu kopuza sahip olmayı başarır. Kurdun yiğide verdiği güç ile "ok" yarışlarında bu yiğit birinci olur ve hanın kızını alır (Ögel 2002, 116). Güney Sibirya sakinlerinden Dolgan Türkleri arasında ise kurt ile ilgili şöyle bir efsane anlatılmaktadır: Güçlü bir bakş1, bir gün insanların bütün maralları tuzağa düşürerek öldürdüğünü görür. Başka bir gün onların yanına karşı taraftan bir yerden kürk giyen bir adam gelir. Adam, insanlara bakmadan bir maralı öldürür; sonra da oradan uzaklaşıp gider. İnsanlar bu adamın kuyruğu olduğunu görür. İnsanlar akşam evlerine gidip yemeklerini yerken bu adam tekrar gelir ve insanların ahırlarına girer. Sonra da insanların kaldığı çadıra girer. İnsanlar onun kuyruğunun kar olduğu fark eder. Adam kuyruğundaki karı silkmeye çalışırken insanlar, onun bir insan değil kurt olduğunu anlar. Onların bakşısı bu kurdu insana dönüştürür. Yalnız olduğu bir sırada kurt, kuyruğunu da baltayla keser ve ondan sonra insanlarla yaşamaya başlar (Ergun 1997, 841-842). "Karşl taraftan bir yerden gelen kuyruklu, meçhul adam", kurt olduğu için ve diğer mitolojilerde Sirius'tan gelip bir süre halkla beraber yaşayan kurt başlı atalardan bahsedildiği için bu kurt adamın, Sirius ile ilişkili olduğu düşünülebilir.

Türk mitolojisi-Sirius Takımyıldızı ilişkisi ile ilgili olarak ele alınabilecek son motif, köpek motifidir. Yaşar Çoruhlu, "Türk Mitolojisi'nin Ana Hatları" isimli kitabında yol gösterici kurt gibi Türklere yol gösteren bir köpekten bahsetmektedir. Çoruhlu, Süryani Mihael'e ait bir eserden alıntı yaparak Türklerin doğudan batıya ilerlemeye başladıkları sırada önlerine köpeğe benzer bir hayvan çıktığını ve bu hayvan yürüdüğü zaman Türklerin de yürüdüğünü, durduğu zaman Türklerin de durduğunu; durdukları yere ordugâhlarını kurduklarını belirmiştir (Çoruhlu 2006, 114).

Ebulgazi Bahadır Han Oğuz Kağan Destanı'nda, Hint Okyanusu kıyılarında yaşayan ve “It Barak" adı verilen kabilelerden söz etmektedir. Oğuz Kağan ile bu kabile arasında büyük bir vuruşma olmuştur. $\mathrm{Bu}$ vuruşma sonucu Oğuz Kağan ve askerleri bozguna uğramıştır; Oğuz Kağan da askerlerini alarak iki ırmak arası bir yere çekilmek zorunda kalmıştır (Ögel 2003, 186). Türk mitolojisinde iki irmak arasında kalan yerler genellikle kutsal adalar olarak bilinmektedir. O zaman Çin mitolojisindeki kutsal adalar ile Oğuz Kağan'ın bulunduğu iki ırmak arası yer, aynı bölge olabilir ve köpek başlı ya da köpeğe benzeyen insanların bu bölgede yaşadığı kabul edilebilir. Reşidüddin'in Câmi'ut-tevarih eserinin Hafiz Abrû (Hafiz-i Ebru) Mecmuası içerisinde yer alan Oğuzname nüshasında (Târih-i Türkân û Oğuz û Hikâyet-i Cihangırî-i û / Türklerin ve Oğuz'un Tarihi ve Onun [yani Oğuz Han'ın] Cihangirliğinin Hikâyesi. Câmi'ut-tevârih'in Topkapı Sarayı Hazine Kütüphanesi bölümünde nr. 1653'te bulunan bölüm: Sümer 1959, 359) ise Oğuz Han'ın kuzeyde, İdil Nehri'nin ötesinde ve karanlık ülkesinde oturan "Kll-Barak" (İt-Barak) kavmine karş1 harp etmeye karar verdiği yazmaktadır. Verilen bilgiye göre Kıl-Barak erkeklerinin yüzleri, köpek yüzüne benzemektedir; kadınları ise güzeldir. Oğuz Kağan başta bu kavme yenilmiştir; ancak, aradan on yedi y1l geçtikten sonra tekrar dönüp bu kavmi yenmiştir. Bu Kıl-Barak kavmi ile Kıpçaklar arasında bir akrabalık olduğu da belirtilmektedir. Bu da muhtemelen Oğuz Kağan'ın Kıl-Barakların üzerine yaptığı ilk sefer sirasında askerlerinden birinin güzel Kıl-Barak kadınlarından biri ile birlikte olması ve Oğuz Kağan'ın askerlerinin bozguna uğrayarak geri çekildikleri sırada bu kadının bir ağaç 
kovuğunda doğum yapması, babası harpte öldüğü için Oğuz Kağan'ın ağaç kovuğunda doğan bu çocuğu evlat edinerek ona "Kıpçak" adını vermesi sonucunda ortaya çıkan bir akrabalık ilişkisidir. Kıpçak büyüdükten sonra Oğuz Kağan onu, Kıl-Barakları idare etmesi için kuzeye göndermiştir (Ögel 2003, 188-190). "Barak” kelimesi Türkçede "varan, çok çabuk yürüyen ve koşan" manasına gelmektedir. Kaşgarlı Mahmud "barak" kelimesini şöyle açıklamıştır: "Çok tüylü bir köpektir. Türklerin inancına göre Kerkes kuşu kocayınca iki yumurta yumurtlar ve bunların üzerine oturur imiş. Bu yumurtaların birinden 'barak' adlı bir köpek çıkarmış. Barak, köpekler içerisinde en iyi koşan ve en iyi av avlayan bir cins imiş. Öbür yumurtadan da bir başka yavru çıkarmış. Bu yumurta da artık o kuşun son yavrusu olurmuş" (Ögel 2003, 191). Kaşgarlı Mahmud'un bahsettiği bu kuş, Kazak inanışında karşımıza "Kurmay kuşu” adı ile çıkar ve Kazaklar da bu kuşun yumurtasından bir köpeğin çıktığı rivayetini anlatmaktadır (Salt 2010, 223). Kerkes veya Kurmay kuşu Türk mitolojisinde, sürekli olarak küllerinden yeniden doğan Zümrüd-ü Anka kuşu adıyla da geçer. İnanışa göre bu kuş bin yıl yaşar, sonra bir tür ateş olup kendi kendini yakar ve kendisinden yeniden doğar. Sonra tekrar bin yıl yaşar ve aynı şeyi yapar. Bu kırk dokuz kez böyle devam eder (Salt 2010, 113). Kaf Dağı'nın ardında yeri asla bulunamayan Zümrüd-ü Anka'nın anlatılanlara göre doğaüstü bir canlı olduğu muhakkaktır. Bu doğaüstü canlıdan olağanüstü bir şekilde bir köpeğin doğması ve aynı zamanda bu canlının kendini kırk dokuz kez öldürüp diriltebilmesi bize Sirius bağlantısı açısından ilginç ipuçları vermektedir.

Hakas Türklerine ait Köketey efsanesi birebir Sirius adının geçtiği nadir anlatmalardandır; zaten “Köketey”, Hakas Türkçesinde "Sirius”un karşılı̆̆ıdır. Ayrıca bu efsane, kuş yumurtasından çıkan köpek motifinin yer aldığı anlatmalardan biridir. Efsanede Köketey, öksüz bir çocuktur. Bir gün bir güvercin yumurtası bulur. Bu yumurta çatladığında içerisinden kara kulaklı ak bir yavru köpek olan "Humay Hus" çıkar. Humay Hus büyüyünce kuşları uçurtmadan tutan, hayvanları kaçırtmadan yakalayan bir avcı köpeği olur. Günün birinde bir Moğol Beyi, Humay Hus'u almak ister. Karşıllğında da inek ve gök aygırlı yılkı sürüsü vermeyi teklif eder. Öksüz oğlan bu teklifi kabul eder ve Moğol Beyi'nin verdiği mallarla çok zengin olur. Ona artık “Gök Atlı Köketey" denir. Bu arada Humay Hus da Moğol Beyi'nin ölmek üzere olan oğlu için kimsenin yenemediği canavarı yenip bu canavarın kalbini ve ciğerini çıkartarak Moğol Beyi'nin oğluna getirir ve çocuk iyileşir. Bundan sonra üç yıl Humay Hus, sahibi hiç ava çıkmadığı için, zincire bağlı olarak bekler. Sonunda bir gün dayanamaz, zincirini kırar ve eski sahibine doğru yola çıkar. Köketey de bu olayı rüyasında görür ve ok ile yayını alarak gök atına biner ve Humay Hus'a doğru yola çıkar. Karşılaştıktan sonra yola birlikte devam ederlerken Humay Hus iki oğlaklı bir sığını kovalamaya başlar. İyeli üç gölün olduğu bir yere kadar sığını kovalar. Sığın, göl iyelerine kurtarılmaları için yalvarır. Üçüncü göl iyesi onlara acır, yanına alır ve Humay Hus'a da bir oyun oynayarak onu demir bir tasma ile göle doğru sürükler. Humay Hus'un sürüklendiği yerde bir nehir oluşur ve bu nehre Humay Hus Nehri denir. Köketey gelip bu manzarayı görünce sığına beddua eder; sığın iki yavrusu ile birlikte taş olur kalır ve ruhları da göğe çıkıp Orion'un üç yıldızı olur. Bu olanları gören gökteki Toğıs Çayaçı çok kızar ve Humay Hus'un ruhunu yıldıza dönüştürüp üç Orion yıldızının arkasına asar. Köketey'i de gök atı ile birlikte taş ettikten sonra onun ruhunu da parlak yıldız Köketey'e yani Sirius'a dönüştürüp Humay Hus yıldızının altında bir yere koyar (Ergun 1997, 745-747).

Bir Kırgız efsanesinde "Balta Cutar" adlı yırtıcı bir kuşun yüksek dağlarda "Kumayık" adında bir köpek yavrusu doğurduğu anlatılmaktadır. Efsaneye göre bu yavru üç gün içerisinde insanlar tarafından bulunursa köpeklerin ulu beyi, efendisi ve insanların doğaüstü kötü varlıklardan koruyucusu olarak insanlar için kutsal bir varlık şekline girer yoksa annesi gibi yırtıcı bir kuşa dönüşür. Efsanenin devamında Kumayık'ın tüm halklarda ünlü kişilerin yanında 
olduğu anlatılmaktadır. Köykap Dağı'ndan yeryüzüne çıkan canavarı hisseden Kumayık'ın yedi günlük bir mesafeden havladığı ve bu canavarın Kumayık'ın olduğu yere giremediği de anlatılanlar arasındadır (Akmataliyev \& Kırbaşev 2001, 164-165). Kuştan doğan köpek motifini bir kez daha gördüğümüz bu efsanede kutsal varlık Kumayık'ın da Sirius kültürü içerisinde bir yeri olması muhtemeldir.

Kırgız Türklerine ait başka bir efsanede Kırgızların, kendilerinin refah ve bolluk içerisinde bıraktıkları kamplarını daha sonra yerle bir olmuş halde bulan kırk bakirenin, karşılarına çıkan başıboş ve vahşi köpeklerle birleşmelerinden doğdukları anlatılmaktadır (Roux 2008, 87). Kırgızların isimleri bu "kırk kız"dan gelmektedir. Kurt ile birleşme bu efsanede yerini köpek ile birleşmeye bırakmıştır. Siriusyen kültür bunu coğrafi değişiklik sonucu olmuş olan bir hayvan değişmesi olarak görmez; bu kültüre göre Sirius'tan gelen tanrılar veya elçileri bazen bir kurt bazen de bir köpek olabilmektedir. Her iki hayvan da Sirius’un bir sembolüdür.

Murat Uraz "Türk Mitolojisi” adlı eserinde Tatarların kırmızı bir köpek ile bir Tatar prensinin soyundan geldiklerine inandıklarını belirtmiştir; fakat bir kaynak göstermemiştir (Uraz 1967, 112).

Başkurt Türkleri arasında anlatılan köpek efsaneleri incelendiğinde iki efsane, Sirius ile ilişkilendirilebileceği için dikkat çekmektedir. İlk efsanede doğurduğu çocukların hiçbiri yaşamayan bir kadına çocuğu olursa bir köpeğe emzirmesi söylenir. Bir zaman sonra bu kadın tekrar çocuk sahibi olur ve bu çocuğu dişi bir köpek bulup emzirir ve çocuk yaşar. Zamanında bu çocuğun yaşadığı köye "İt Emmiş Köyü" denilir (Süleymanov 2001, 421). Dişi kurt tarafından emzirilen olağanüstü kahramanlardan sonra karşımıza bu efsane ile dişi bir köpek emzirdiğinde hayatta kalmayı başaran bir çocuk çıkmıştır. İkinci efsane ise Köktüş (Gökgögüs) adlı bir avc1 köpeğinden bahseder. Köpeğin sahibi olan avc1 bir gün ormanda bir yiğit ile karşılaşır. Bu yiğit, avcının köpeğine sahip olmak ister ve bu köpek karşıllğında avcı için gölden at çıkaracağını söyler. Avcı bu teklifi kabul eder. Yiğit, köpek ile birlikte gölün dibine dalar ve bir kısrak ile geri gelir. Avcıya, bu kısrakla beraber dönüp arkasına bakmadan yoluna devam ederse gölden yılkı çıkacağını söyler ve köpeği de yanına alarak kayıplara karışır. Bu efsanede başta köpeğin adı dikkati çekmektedir. "Gökgöğüs" ile köpeğin tanrısal bir özellik taşıdığ1 belirtilmiştir. Bu herhangi bir av köpeği olmadığı için ve çok değerli bir varlık olduğu için ormanda aniden ortaya çıkan yiğit ona sahip olmak istemiştir ve karşılığında avcıya mucizevi atlar takdim etmiştir. Büyük ihtimalle, bu köpeğin gökselliğinin yanı sıra ormanda avcının karşısına aniden çıkan yiğidin de Sirius ile bir ilişkisi vardır; çünkü o da köpek karşılığında gölden yılkı çıkartma mucizesini göstererek avcıya bu yılkıyı sunmuştur.

Karaçay-Malkar Türklerinde köpek motifi araştırıldığında onların, Ay tutulmasına sebep olan "Celmavuz" adlı ejderhadan ve Ay'1 koruyan "Jolbars" ve "Albars" adındaki iki çoban köpeğinden bahsettikleri görülmektedir. $\mathrm{Bu}$ çoban köpekleri ne zaman uyumaya kalksa Celmavuz'un gelip Ay’1 yemeye çalıştı̆̆ına inanılır. Halk da uyuyan bu iki köpeği uyandırmak için silah atıp davul çalar (Doğan 2001, 623). Astronomide köpek ile temsil edilen Büyük Köpek Takımyıldızı'na mensup iki yıldızın Sirius A ve Sirius B olması, halk inancında Ay'ın koruyucusu olan bu iki çoban köpeği ile kastedilenlerin Sirius yıldızları olabileceğini düşündürmektedir.

Altayların Yaratılış Destanı'nda insanoğluna göz kulak olması için bırakılan köpek, Altay Türklerine ait bir efsanede daha karşımıza çıkmaktadır. Bu efsanede Bırkan, çamurdan insan yaratıp can vermek için bir şeyler aramaya gider ve insana köpeği bekçi bırakır. $\mathrm{Bu}$ arada yeraltından Erlik çıkar ve insanı canlandırır. Bırkan tekrar geldiğinde insanın canlanmış olduğunu görür ve köpeği kovar. Bu efsanenin sonunda kadınların köpeklere ayakları ile 
vurmadığı ve onları dövmediği; çünkü köpeklerin Bırkan'ın kardeşi olduğu için kutsal sayıldığ1 belirtmiştir (Dilek 2002, 573). Çuvaş Türklerinde de insanoğlu için tanrı tarafindan bekçi bırakılan köpek ile ilgili benzer bir efsane anlatılmaktadır (Yılmaz 2001, 507). (Ayrıca Altay inanışlarında öteki alemin açılması gereken köprüsünün başında bir köpeğin beklediği söylemiştik.) Bunun dışında Altay ve Güney Sibirya halklarının destanlarında Cedey Han'ın yedi köpeğinin Altın Dă̆'ın kapısında nöbet beklediği söylenmektedir (Ögel 2002, 208). Burada muhtemelen Cedey Han ile Büyükayı Takımyıldızı, Altın Dağ ile Kutup Yıldızı ve yedi köpek ile de Sirius Yıldızı işaret edilmektedir.

"Sarı Köpek” adlı bir Altay masalında oduna giden bir ihtiyara, sarı bir köpek musallat olur. İhtiyar bu köpeğe kızlarından birini vereceğine söz verince köpek onu bırakır. İhtiyarın küçük kızı sarı köpek ile evlenmeye razı olur. Köpek kıza, aslında bir insan olduğunu söyler. Kızın ablaları köpeğin derisini ateşe verir. Buna kızan köpek her şeyi yumurtaya dönüştürüp göğe çıkar. Eşi de peşinden göğe çıkar. Onlar gökyüzünde huzurlu yaşarlar (Dilek 2007, 207).

Tuva Türkleri, Tanrının bütün canlıları yaratırken içlerinde sadece insanların ve köpeklerin birbirlerini anlayacak şekilde yaratıldığına ama köpeklerin bütün insanların sırlarını birbirlerine ve başkalarına anlatarak çok konuştuğu için Tanrı tarafından susturulduğuna; o günden sonra da görevlerinin sadece insanları korumak ve gelecek tehlikeleri önceden bildirmek için havlamak olarak Tanrı tarafından belirlendiğine inandıkları bir efsane anlatır (Arıkoğlu 2001, 641). Tuva Türklerine ait bir başka efsanede köpek, bir kızın şaman özelliği kazanmasına yardım etmiş olarak anlatılmaktadır ve bu köpeğin şekil değiştirebilen kötü ruh Şulbus olduğu söylenmektedir; ama bu efsanede kıza bir kötülüğü dokunmamıştır. Efsanede anlatıldığına göre, Oyun adında bir kız her gün sevgilisinin yolunu gözler ama bir zaman sonra oğlan gelmemeye başlar. Bir gün oğlanın kuzey ovada bir malcıya iç güveyi gittiği duyulur. Oyun olan biteni gözleri ile görmek ister ama oğlanın olduğu yer çok uzaktır. Bir akşam yaya olarak gitmeye karar verir. Yolda kızıl bir köpeğe rastlar. Köpek, Oyun'dan kaçmaz; daha çok ona yardım edecek gibi görünür. Köpekten korkusu biraz geçince Oyun, ne yaptığını anlamadan, birden köpeğin üzerine biner. Köpek adeta uçar gibi oğlanın iç güveyi yaşadığı eve doğru koşmaya başlar. Oyun, köpek sayesinde oğlanı iç güveyi gittiği evde kendi gözleri ile görür. Sonra tekrar bu köpek sayesinde evine döner. Oyun daha birçok kez bu köpeğe binerek bu eve gelip gider ve daha sonra bu köpeğin yardımı ile şaman özelliği kazanır (Arıkoğlu 2001, 621).

Bir Şor efsanesinde kahraman Kan Ergek, eskiden kır atlı bir yiğittir. Bu yiğidin dokuz tane de köpeği vardır. Bir gün Kan Ergek ve köpekleri bir geyik kovalarken geyik birden sıçrayıp göğe çıkar. Kan Ergek de üç köpeği ile birlikte sıçrayıp göğe çıkar. Gökyüzünde kovalamaca devam ederken Kan Ergek'in atı yorulur ve olduğu yerde bir yıldıza dönüşür. Buna çok kızan Kan Ergek de "ok"unu çıkartıp geyiğe doğru atar. O an geyik de bir yıldıza dönüşür. Onların ardından da Kan Ergek, onun üç köpeği ve attığı ok birer yıldıza dönüşür (Ergun 1997, 864). Teleüt Türkleri tarafından anlatılan benzer efsane şöyledir: Bir zamanlar usta bir avcı olan yetim bir oğlan avlanırken insanlar ona Tanrı istediği için mi hayvanları öldürdüğünü yoksa kendi iradesi ile mi davrandığını sorar. Bir av köpeğine sahip olan bu oğlan cevap olarak "Tanrı kim oluyor da benim yanımda! Neyi öldürmek istersem onu öldürürüm; neyi vurmak, avlamak istersem onu avlarım" der. Bu olay üzerine oğlan bir gün ava çıktığında yolda üç geyik görür ve onları kovalamaya başlar. Geyikler de sıçrayıp göğe çıkar. Avcı da köpeği ile birlikte geyiklerin peşinden göğe çıkar. Burada hepsi yıldıza dönüşür; hatta avcının kana bulanmış oku bile gökyüzüne bakıldığında görülür (Ergun 1997, 869). Efsanenin sonuna kadar oktan hiç bahsedilmese de Şorların efsanesi ile olan benzerliğinden avcının geyikleri vurmak için ok attığ tahmin edilmektedir. Telengit Türklerinden "Yıldıza Dönen Avcı ve Geyikler" adı ile derlenen 
efsanede ise Kobon adında bir avcı, üç geyik kovalar. Geyiklerin üzerine köpeklerini salar; fakat köpekler, geyikleri tutamaz. Bunun üzerine Kobon geyiklere bir ok atar. Ok, geyiklerden birinin kalbini delip geçer. Bugün bu geyikler, avcının köpekleri ve avcının attığı ok gökyüzünde yıldız halinde görülmektedir (Ergun 1997, 873).

\section{Sonuç}

Dünya mitolojilerinde Sirius A ve Sirius B çiftinden oluşan Sirius Takımyıldızı ile ilgili anlatmalar sonucu Sirius ile ilgili olan mitolojik unsurların gök tanrı, 1şık, yıldız, ok ve yay, kurt ve köpek olduğu tespit edilmiştir. Bu unsurlar Türk mitolojisi açısından ele alındığında Oğuz Kağan, Bozkurt, Ergenekon ve daha birçok Türk destanında; Altay, Kırgız, Kazak, Karakalpak, Hakas, Tuva, Başkurt, Karaçay Malkar, Tatar, Dolgan, Yakut, Baraba-om, Kazan ve Çuvaş Türklerinin efsanelerinde ve masallarında "Sirius" adı verilerek birebir anlatmalar bulunmasa da önemli benzerlikler bulunduğu açıktır. Dünyanın en gelişmiş medeniyetleri arasında Sirius kültürü açısından çok sayıda paralellik olmasının temelinde muhtemelen aynı etki yatmaktadır. Bugün elimize ulaşmayan ve çok eski olduğu tahmin edilen Türk kaynaklarında Sirius ile ilgili bilgilerin olması muhtemeldir.

\section{KAYNAKÇA}

Adiloğlu A. (2001). “Kafkas Nart Destanlarında Sümer ve Saka İzleri”. Bilge 31/Kış (2001) 29-32.

Adiloğlu A. (2007). "Karaçay-Malkar Nart Destanları". Türkoloji Araştırmaları 2/1 (2007) 196-218.

Akmataliyev A. \& Kırbaşev K. (2001). "Kırgızistan”. Türk Dünyası Ortak Edebiyatı, Türk Dünyası Edebiyat Metinleri Antolojisi (Cilt 1) 140-191. Ankara 2001.

Arıkoğlu E. (2001). “Tuva Türkleri”. Türk Dünyası Ortak Edebiyatı, Türk Dünyası Edebiyat Metinleri Antolojisi (Cilt 1) 580-657. Ankara 2001.

Aslan N. (2010). "Kurt Motifinin Türk Menşe Efsanelerindeki Anlamı Üzerine”. Milli Folklor 22/87 (2010) 72-77.

Banarlı N. S. (2001). Resimli Türk Edebiyatı Tarihi. Cilt 1. İstanbul 2001.

Bang W. \& Arat R. R. (1936). Oğuz Kağan Destanı. İstanbul 1936.

Black J. \& Green A. (2003). Mezopotamya Mitolojisi Sözlüğ̈̈-Tanrllar, Ifritler, Semboller. İstanbul 2003.

Bonnefoy Y. (2000). Antik Dünya ve Geleneksel Toplumlarda Dinler ve Mitolojiler Sözlügüu. Ankara 2000.

Campbell J. (1998). Doğu Mitolojisi. Ankara 1998.

Candan E. (2002). Türklerin Kültür Kökenleri. İstanbul 2002.

Çobanoğlu Ö. (2007). Türk Dünyası Epik Destan Geleneği. Ankara 2007.

Çoruhlu Y. (2006). Türk Mitolojisinin Ana Hatları. İstanbul 2006.

Dilek İ. (2002). Altay Destanları 1. Ankara 2002.

Dilek İ. (2007). "Sibirya Türk Masallarında Hayvanla Evlenme". Türkiyat Araştırmaları Dergisi 22 (2007) 207-218.

Doğan L. (2001). “Türk Kültüründe Hayvanlar ve Hayvan İsimleri”. Türk Dünyası Dil ve Edebiyat Dergisi 12/2 (2001) 615-659.

Emmanuel R. (1995). Hint, Yunan ve Misır Mitolojilerinde Gizemli Bilgilerin Kaynakları. İstanbul 1995.

Ergun M. (1997). Türk Dünyası Efsanelerinde Değişme Motifi. Cilt 2. Ankara 1997.

Estin C. \& Laporte H. (2007). Yunan ve Roma Mitolojisi. Ankara 2007.

Grimal P. (1997). Mitoloji Sözlüğ̈̈, Yunan ve Roma. İstanbul 1997.

Günay Ü. \& Güngör H. (2007). Başlangıçtan Günümüze Türklerin Dini Tarihi. İstanbul 2007.

Holberg J. B. (2007). Sirius: Brightest Diamond in the Night Sky. Chichester 2007. 
Homeros (2008). İlyada. Çev. Azra Erhat. İstanbul 2008.

Hope M. (1994). Atlantis - Efsane mi Yoksa Gerçek mi?. İstanbul 1994.

Hope M. (1998). Eski Misır ve Sirius Bağlantısı. İstanbul 1998.

Kafesoğlu İ. (2007). Türk Milli Kültürü. Ankara 2007.

Kalafat Y. (1999). Kırım Kuzey Kafkasya. Ankara 1999.

Kaya K. (1997). Hint Mitolojisi Sözlüğü. Ankara 1997.

Kramer S. N. (2001). Sümer Mitolojisi. İstanbul 2001.

Mackenzie D. A. (1996). Çin ve Japon Mitolojisi. Ankara 1996.

Minnegulov H. (2001). "Kazan Türkleri”. Türk Dünyası Ortak Edebiyatı, Türk Dünyası Edebiyat Metinleri Antolojisi (Cilt 1) 352-405. Ankara 2001.

O’flaherty W. D. (1996). Hindu Mitolojisi. Ankara 1996.

Ögel B. (1982). Türklerde Devlet Anlaylşı (13. Yüzyllın Sonuna Kadar). Ankara 1982.

Ögel B. (2002). Türk Mitolojisi. Cilt 2. Ankara 2002.

Ögel B. (2003). Türk Mitolojisi. Cilt 1. Ankara 2003.

Ramazanoğlu M. (1998). Gllgamış Destanı. İstanbul 1998.

Roux J. P. (2008). Türklerin Tarihi / Pasifik'ten Akdeniz'e 2000 Yll. İstanbul 2008.

Sakaoğlu S. \& Duymaz A. (2002). İslamiyet Öncesi Türk Destanlarl. İstanbul 2002.

Salt A. \& Çobanlı C. (2001). Dharma Ansiklopedisi. İstanbul 2001.

Salt A. (2010). Semboller Ansiklopedisi. İstanbul 2010.

Süleymanov A. (2001). "Başkurt Türkleri”. Türk Dünyası Ortak Edebiyatı, Türk Dünyası Edebiyat Metinleri Antolojisi (Cilt 1) 406-481. Ankara 2001.

Sümer F. (1959). "Oğuzlara Ait Destani Mahiyette Eserler”. Ankara Üniversitesi Dil ve Tarih Coğrafya Fakültesi Dergisi 17/3-4 (1959) 359-389.

Şenel A. (2009). Kemirgenlerden Sömürgenlere İnsanlık Tarihi. Ankara 2009.

Temple R. (1999). Sirius Gizemi. İstanbul 1999.

Uluışı Y. P. (2015). Türk Destanlarında Yeraltı Dünyası (Sibirya Sahası). Yayımlanmamış Doktora Tezi. Gazi Üniversitesi, Ankara 2016.

Uraz M. (1967). Türk Mitolojisi. İstanbul 1967.

Werner E. T. C. (2008). Çin Mitleri ve Efsaneleri. İzmir 2008.

Yılmaz M. (2001). "Çuvaş Türkleri”. Türk Dünyası Ortak Edebiyatı, Türk Dünyası Edebiyat Metinleri Antolojisi (Cilt 1) 482-553. Ankara 2001. 